Our Nature (2009) 7:56-81

\title{
The Birds of Sukla Phanta Wildlife Reserve, Nepal
}

\author{
H.S. Baral ${ }^{*}$ and C. Inskipp ${ }^{2}$ \\ ${ }^{1}$ Himalayan Nature, PO Box 10918, Lazimpat, Kathmandu, Nepal \\ ${ }^{2} 1$ Herneside, March Road, Welney, Wisbech, Cambridgeshire PE14 9SB, UK \\ *E-mails: hem.baral@gmail.com; inskipp@btinternet.com
}

Received: 19.10.2009, Accepted: 05.012.2009

\begin{abstract}
Sukla Phanta Wildlife Reserve lies in the southwest corner of Nepal. It has been listed as an important bird area and a number of bird studies have been conducted here. The reserve is an important refuge especially for many grassland birds, several of which are globally threatened. The high, total of 15 globally threatened and 13 near-threatened bird species occur in Sukla Phanta. Some of the bird species reach their world limit of distribution at Sukla Phanta. Of all the habitats found in Sukla Phanta, grassland is the most important. Conservation and management of grasslands that are sympathetic to bird populations are urgent at Sukla Phanta.
\end{abstract}

Key words: Sarcogyps calvus, globally threatened birds, Sukla Phanta Wildlife Reserve, Nepal

\section{Introduction}

Sukla Phanta $\left(28^{\circ} 53^{\prime} \mathrm{N} \& 80^{\circ} 11^{\prime} \mathrm{E}\right)$ lies in the extreme southwest of the terai in Kanchanpur District. It is one of Nepal's smaller protected areas covering $305 \mathrm{~km}^{2}$ and ranges in altitude from $150 \mathrm{~m}$ to $600 \mathrm{~m}$ (WWF Nepal, 2000). The international border between Nepal and India demarcates the southern and western boundaries of the reserve. The Luggabugga Florican Reserve in India lies adjacent to the southern boundary of Sukla Phanta. The Syali and Radha rivers form the eastern and western boundary respectively for the part of the reserve that extends north of the east-west highway (Figure 1).

The reserve was a famous hunting area for many years and was declared as a Royal Hunting Reserve in 1969 with an area of about $155 \mathrm{~km}^{2}$. The reserve was gazetted as the Sukla Phanta Wildlife Reserve in 1976. Later the reserve was extended eastwards by an area of about $150 \mathrm{~km}^{2}$ to create more habitat and a corridor from the terai into the Churia hills for the seasonal migration of wildlife. Sukla Phanta is important both nationally and internationally for its extensive grasslands or phantas that constitute almost half the reserve's vegetation and a much greater area than grasslands in the rest of lowland Nepal. The main grassland, Sukla Phanta proper, is the largest protected patch of continuous grassland in Nepal. It is approximately 16 $\mathrm{km}^{2}$ in area. The main grass species include Imperata cylindrica and Heteropogon contortus. In the eastern half of the main phanta the grassland is damp with large areas of marshes and pools. There are other smaller phantas in the reserve which are also important for birds. These are Singhpur Phanta, Karaiya Phanta, Dudhiya Phanta, and some smaller phantas near Jhilmila and 


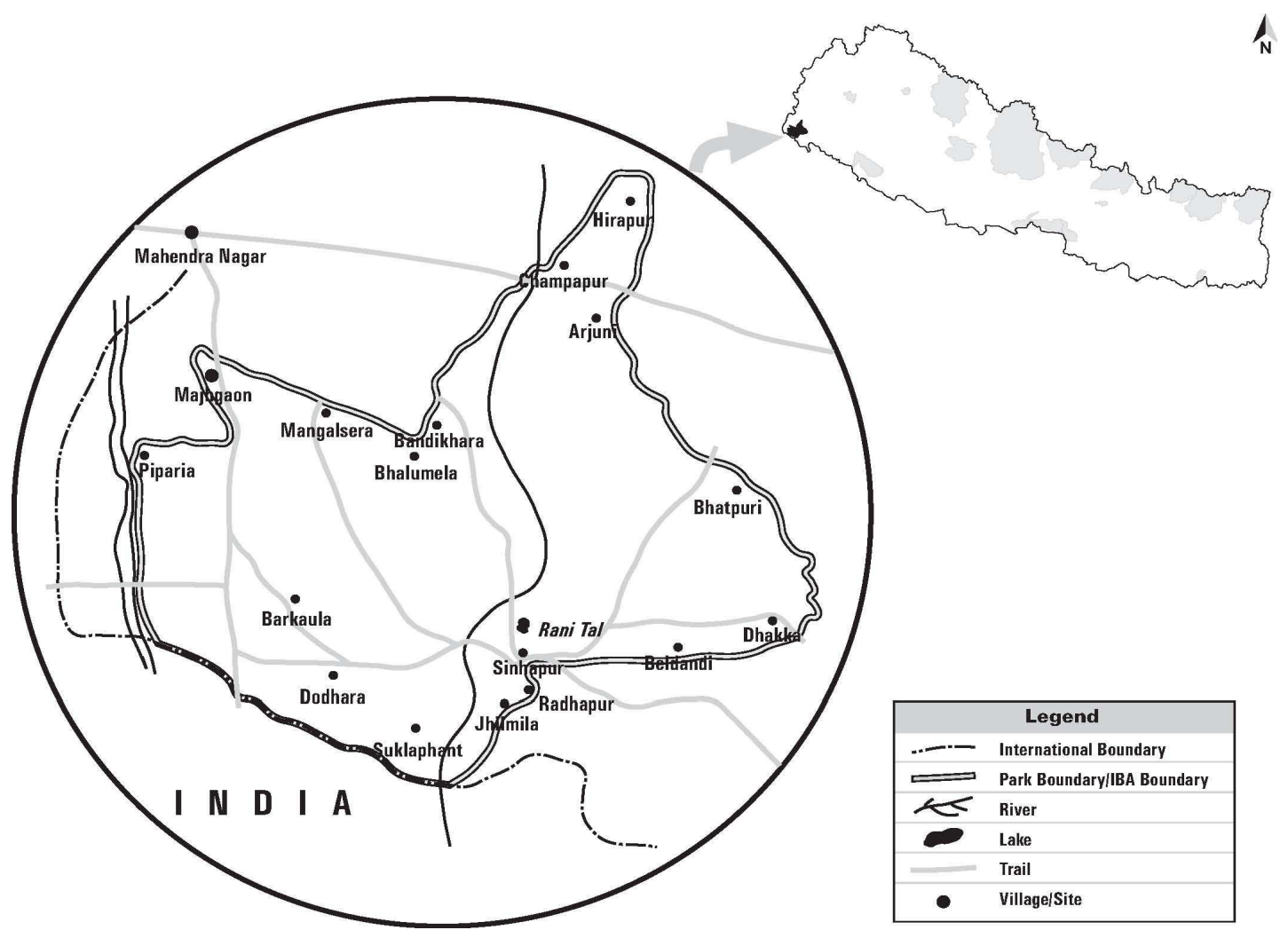

Figure 1. Sukla Phanta Wildlife Reserve, Nepal.

Radhapur (Baral, 1998b).

Sal is the dominant forest type in the reserve with Khair Acacia catechu and Sisso Dalbergia sissoo alongside rivers. There are seven small lakes, Rani Tal, Salghaudi Tal, Kalikitch Tal, Bhatpuri, Kumari, Shikari and Tara Tal, with associated marshes where dense grasses of Phragmites karka and Saccharum spontaneum predominate. These wetlands add significantly to the biodiversity of the reserve. Shikari Tal is basically a vast area of associated marshes with scattered open pools and is the least explored of all. Sukla Phanta has a hot, dry monsoon climate.

\section{Results and discussion \\ Avifauna}

A total of 423 bird species has been recorded from the reserve- a high number for such a small area (Appendix for full list). For comparison, Chitwan National Park, which also lies in the lowlands, covers three times the area of Sukla Phanta and has a species total of 541 species (Baral and Inskipp, 2005; Giri and Choudhary, 2008).

Sukla Phanta is the limit for world distribution for several grassland bird species. It is the western limit of the following species: Swamp Francolin Francolinus gularis, Jerdon's Bushchat 
H.S. Baral and C. Inskipp/ Our Nature (2009) 7: 56-81

Saxicola jerdoni, Rufous-rumped Grassbird Graminicola bengalensis and Chestnutcapped Babbler Timalia pileata. The reserve is also the north-western limit of the nominate race of Yellow-eyed Babbler Chrysomma sinense sinense, the western limit for the griseigularis race of Jerdon's Babbler Chrysomma altirostre and the eastern limit of the nominate race of Finn's Weaver Ploceus megarhynchus megarhynchus (Baral, 2000). Sukla Phanta is the most important regular wintering site of Hodgson's Bushchat Saxicola insignis.

A number of species typical of western Nepal occurs on the reserve including White-naped Woodpecker Chrysocolaptes festivus, Brown-capped Pygmy Woodpecker Dendrocopos moluccensis, Brown-headed Barbet Megalaima zeylanica, Sarus Crane Grus antigone, Tickell's Blue Flycatcher Cyornis tickelliae, Jungle Prinia Prinia sylvatica and Tawny-bellied Babbler Dumetia hyperythra.

Two species new for Nepal, Finn's Weaver Ploceus megarhynchus, formerly considered an Indian endemic and Singing Bushlark Mirafra cantillans were found on the main grassland at Sukla Phanta during fieldwork carried out in 1996 showing how poorly its avifauna was known until that time (Baral, 1998b). Parts of the reserve are still poorly known ornithologically. The extension area on the eastern half of the reserve is still largely unsurveyed. The marshy eastern half of the main phanta (4.5 $\mathrm{km}^{2}$ ) remains inaccessible for most of the year and has rarely been visited by ornithologists (Baral, 1998b).

A total of 33 bird species that occur in Nepal has been identified as globally threatened with extinction by BirdLife International (BirdLife International, 2009). Fifteen of these ( $48 \%$ of the total) have been recorded in Sukla Phanta (Table 1). Over half of the reserve's globally threatened birds frequent grasslands emphasising its importance for this habitat type. All of these species are at risk internationally because of loss, fragmentation and degradation of grasslands.

The reserve supports the highest population of Bengal Floricans Houbaropsis bengalensis in Nepal. The main phanta is by far the most important for the species. Surveys for Bengal Florican were carried out in 1982 (Inskipp and Inskipp, 1983), 1990 (Weaver, 1991), 2000 (Baral et al., 2003) and 2007 (Poudyal et al., 2008a, b). The number of males remained stable at 1214 birds in the 1982, 1990 and 2000 survey, but only 8-9 males were located in 2007, indicating a decline of $38 \%$ compared to the 1982 survey.

The species requires areas of short grass, preferably Imperata cylindrica for feeding and as display sites used by males to attract females. Long grass is also needed as escape cover and probably also for nesting (Inskipp and Inskipp, 1983).

Grasslands close to human settlement were found to be overgrazed and disturbed and little used by Bengal Floricans (Baral et al., 2003).

There is only one known report of the closely related Lesser Florican Sypheotides indica at Sukla Phanta, on 5 March 1999 (GC, 1999). The species is probably only a very rare visitor or vagrant to the reserve.

Looking at their present distribution and habitat requirements it can be assumed that the Swamp Francolin was once distributed throughout the southern belt of Nepal where suitable habitat existed. Now the vast majority of birds occur at just two sitesSukla Phanta and Koshi Tappu Wildlife Reserve. It is a locally fairly common 
H.S. Baral and C. Inskipp/ Our Nature (2009) 7: 56-81

breeding resident at Sukla Phanta. Baral (2000) observed there could be well over 100 Swamp Francolins in the reserve. A later survey estimated a maximum of 46 pairs (Singh, 2004). The species density was estimated at 2 birds per sq. $\mathrm{km}$ in $14 \mathrm{sq}$. $\mathrm{km}$ of suitable habitat by Baral (1998c). The population trend of the species at Sukla Phanta is not known. In Nepal the Swamp Francolin is found in tall moist grasslands close to water and with open patches. It prefers grasslands with an average height of 2-3 m. At Sukla Phanta it occurs on the moister eastern grasslands: along a small rivulet from Singhpur to the western marshes of the main phanta and at Jhilmila near the marshes and wetlands created by the meanderings of the Bamni Nala River (Baral, 1998c). Singh (2004) found the main threats in the Jhilmila and Kalikich Lake areas were habitat alteration due to heavy human and livestock pressures, as well as hunting and poisoning of wetlands for fishing in Jhilmila. In the main phanta and Singpur areas predators, drying out of swampy areas during the species' breeding season and the succession of vegetation were the most significant threats (Singh, 2004).

Three passerines that are internationally at risk have good populations on the grasslands of Sukla Phanta: Hodgson's Bushchat, Bristled Grassbird Chaetornis striatus and Finn's Weaver.

Sukla Phanta holds the largest known wintering population of Hodgson's Bushchat. The total wintering population in Nepal is estimated as 100 , more than half of which are restricted to the Sukla Phanta grasslands. The former stronghold and the best known wintering site for the species in Nepal, Koshi Barrage, has suffered habitat loss and alteration and there are very few recent records from this site. The earliest wintering record was 9 November when a single male was observed, and the latest was a male on 6 May 1998 in Sukla Phanta. A survey on 11 December 1997 resulted in the location of 26 individuals in the reserve's grasslands. Fewer females than males were recorded during the surveys. The wintering habitats of Hodgson's Bushchat in the terai are the relatively open and large grasslands. It prefers burnt grasslands with sufficient tall unburnt stems as perches (Baral, 1998d; 1999).

Bristled Grassbird was not recorded on the reserve until May 1996 when up to three birds were found, but had presumably been overlooked previously. In May 1997, 18 birds were heard calling and seen (Baral, 1997c). The species has been recorded in the reserve by a number of other observers since (e.g. Giri and Choudhary, 2001; Inskipp and Inskipp, 2001). The main phanta is the only known site on the reserve for the species. Bristled Grassbird is found in both dry short grasslands as well as grasslands on dry and moist soils. It prefers relatively open short grasslands with tall unburnt reeds or singles of shrubs and medium-sized trees (Baral, 1997c). It is not known whether Bristled Grassbird is just a summer visitor to the reserve or is present all year. Trends in its population at Sukla Phanta are unknown, in common with those of the other threatened and near-threatened passerines that occur in the reserve.

Finn's Weaver is also a fairly common resident in the reserve. Two flocks totalling 11 birds were first seen in May 1996 (Baral, 1998b). The species is found in tall moist grasslands close to marshy/wet areas. At Sukla Phanta the habitat was dominated by vast grasslands of Saccharum with associated Narkat Phragmites karka. The 
grassland was dotted with medium-sized trees and termitaria as tall as $3 \mathrm{~m}$ (Baral, 1998b). A maximum of 53 birds was observed on 24 March 1998 near the main phanta and Jhilmila grasslands (Giri, 1998). The species has subsequently been recorded on the reserve by other observers (e.g. Giri and Choudhary, 2001). Abandoned weaver nests on the edge of the Phragmites marsh at the eastern end of the main phanta were suspected to belong to this species (Hikmat Bisht pers. comm., 1998; Som GC pers. comm., 1999; C. and T. Inskipp pers. obs., 2001). In 2008, a small breeding colony was located at the edge of Shikari Tal (Baral et al., 2008). The small resident population at Sukla Phanta seems to be augmented in summer (Baral, 2000).

Jerdon's Babbler was first recorded at Sukla Phanta on 4 May 1998 when two birds were seen in the wet grasslands by Rani Tal (Giri, 1998). The only other record on the reserve is of at least two birds on 25 April 2001 in wet grasslands behind the dam (Giri and Choudhary, 2001; Inskipp and Inskipp, 2001). The species may well be a rare resident here. It is generally very difficult to see, typically skulking amongst grasses out of sight, although males emerge to sing from the tops of grass stems in the breeding season in early mornings and at dusk.

Populations of White-rumped and Slender-billed Vultures Gyps tenuirostris have rapidly declined in much of Nepal and the rest of the Indian subcontinent. These both species have been listed as critically endangered (BirdLife International, 2009). In 1996 they were common breeding residents in the reserve (Baral, 1996a). On 23 April 2001, a flock of 58 White-rumped Vultures and 13 Slender-billed Vultures was found near Andiya village, just outside the reserve. This was a significantly higher total of these species in one flock than had been recorded by other observers in Nepal during the previous year (Inskipp and Inskipp, 2001). Nesting surveys of both species were carried out on the reserve from 20022004. While totals of 15 and 14 Whiterumped Vulture nests were found in 2002 and 2003 respectively, not a single vulture nest was recorded on the reserve in 2004. The maximum numbers of vultures recorded in flocks in 2004 were 15 White-rumped and eight Slender-billed Vultures (Giri and GC, 2005). The drug diclofenac which has been identified as the cause of drastic vulture declines in the Indian subcontinent (Oaks et al., 2004; Shultz et al., 2004) is widely used on cattle close to the reserve (Giri and GC, 2005).

Lesser Adjutant Leptoptilos javanicus is a fairly common resident and breeds on the reserve. A 2004 population status and distribution survey of the species in the western lowlands located 21 Lesser Adjutants in the reserve; the largest group (eight birds) was found at Baba Lake. Sukla Phanta may be the westernmost locality where these birds breed. At least two nest trees have been located in the south western side of the reserve. Major threats to the stork on the reserve were found to be the drying out of wetlands in summer and poisoning of the Bahunia river system in the reserve to capture fish (Sharma 2005a,b; 2006).

Greater Spotted Eagle Aquila clanga and Lesser Kestrel Falco naumanni are uncommon winter visitors and passage migrants. Schaaf et al. (1980) listed Pallas's Fish Eagle Haliaeetus leucoryphus as resident, but there are no later records from Sukla Phanta. Sarus Crane is rare on the reserve where it is possibly only a visitor, 
H.S. Baral and C. Inskipp/ Our Nature (2009) 7: 56-81

but it is resident and fairly common in cultivation close east of Sukla Phanta. It is recorded frequently from Kali Kitch Tal which lies on the eastern edge of the park.

A total of 13 of Nepal's 24 globally nearthreatened birds has been recorded at Sukla Phanta (Table 2). Seven of these are wetland species and two are fairly common residents on the reserve: Grey-headed Fish Eagle Ichthyophaga ichthyaetus and Darter Anhinga melanogaster. The Grey-headed Fish Eagle and Darter breed (H. S. Baral pers. obs). Black-bellied Tern Sterna acuticauda was formerly a resident seen occasionally (Inskipp, 1989) but is now a rare visitor to Chauhdar river area. On 25 April 2001, 13 Darters were seen in tree tops close to Chaudhar river near Jhilmila. A pair of Black-necked Stork Ephippiorhynchus asiaticus was recorded in Rani Tal in January 1995 (Baral, 1995a, b); single birds were noted till March 1998 (Baral, 1997b; 1998a) and since then there are no known records of this bird from Sukla Phanta. Recent grassland studies have shown that Rufous-rumped Grassbird Graminicola bengalensis is a common, breeding resident on the reserve and is far more common than previously thought. It is skulking and shy, rarely coming in view of an observer except in the breeding season in April and May (Baral, 2000; 2001).

\section{Other birds}

\section{Grassland birds}

In addition to their value for several globally threatened and near-threatened species, the reserve's grasslands and especially the main grassland, Sukla Phanta proper, are important for some other grassland specialities. These include Striped Buttonquail Turnix sylvatica which is fairly common on the main phanta. Bright-capped
Cisticola Cisticola exilis is a common breeding resident in the main phanta. Jerdon's Bushchat Saxicola jerdoni was considered a vagrant but in May 1997 two fledged immatures were seen being fed by two adults at Sukla Phanta. Since the bushchat was first seen on the reserve in May 1996 there have been several records of up to ten birds in the tall marshy grasslands of the reserve in winter and the breeding season. A female type young Jerdon's Bushchat was trapped near Rani Tal in 2002, indicating the species had bred nearby (H. S. Baral, pers. obs.). It is now thought to be a rare and local breeding resident in Nepal. Jerdon's Bushchat is rare elsewhere in the Indian subcontinent and threatened by habitat loss. Blue-breasted Quail Coturnix chinensis, Yellow-legged Buttonquail Turnix tanki and Grass Owl Tyto capensis are three other grassland specialities that have been recorded very rarely at Sukla Phanta and are nationally threatened (Baral and Inskipp, 2004). Grass Owl has not been recorded since the late 1970s (Schaaf et al., 1980).

\section{Wetland birds}

The rivers, ponds and especially the lakes of Sukla Phanta add significantly to be reserve's biodiversity. Rani Tal is the largest and potentially the most interesting of the lakes.

As well as the globally threatened and near-threatened birds given above several nationally threatened species occur on these wetlands. Black Bittern Dupetor flavicollis, Yellow Bittern Ixobrychus sinensis and Striated Grassbird Megalurus palustris are residents recorded frequently at Rani Tal and Salghaudi Tal (Baral and Inskipp, 2004). Black Stork Ciconia nigra is a frequent winter visitor to wetlands and 
H.S. Baral and C. Inskipp/ Our Nature (2009) 7: 56-81

\section{Globally threatened birds}

Table 1. Globally threatened birds recorded in Sukla Phanta, Nepal

\begin{tabular}{|c|c|c|c|}
\hline Species name & $\begin{array}{l}\text { Globally } \\
\text { threatened } \\
\text { status }\end{array}$ & $\begin{array}{l}\text { Status in Sukla } \\
\text { Phanta }\end{array}$ & Habitat \\
\hline $\begin{array}{l}\text { 1. Swamp Francolin } \\
\text { Francolinus gularis }\end{array}$ & VU & br 2 & Grassland \\
\hline $\begin{array}{l}\text { 2. Sarus Crane } \\
\text { Grus antigone }\end{array}$ & VU & $\mathrm{s}, \mathrm{r} ?, 4$ & $\begin{array}{l}\text { Cultivation in well-watered } \\
\text { country }\end{array}$ \\
\hline $\begin{array}{l}\text { 3. Bengal Florican } \\
\text { Houbaropsis bengalensis }\end{array}$ & EN & bs 2 & Grassland \\
\hline $\begin{array}{l}\text { 4. Lesser Florican } \\
\text { Sypheotides indica }\end{array}$ & EN & $\mathrm{m}, 5$ & Grassland \\
\hline $\begin{array}{l}\text { 5. Pallas's Fish Eagle } \\
\text { Haliaeetus leucoryphus }\end{array}$ & VU & br?, w, 5 & Lakes and large rivers \\
\hline $\begin{array}{l}\text { 6. Egyptian Vulture } \\
\text { Neophron percnopterus }\end{array}$ & $\mathrm{E}$ & $\mathrm{w}, \mathrm{r}$ ?, 3 & $\begin{array}{l}\text { Around habitation, open } \\
\text { country }\end{array}$ \\
\hline $\begin{array}{l}\text { 7. White-rumped Vulture } \\
\text { Gyps bengalensis }\end{array}$ & CR & br, 3 & $\begin{array}{l}\text { Around habitation, open } \\
\text { country }\end{array}$ \\
\hline $\begin{array}{l}\text { 8. Slender-billed Vulture } \\
\text { Gyps tenuirostris }\end{array}$ & CR & br, 3 & Around habitation \\
\hline $\begin{array}{l}\text { 9. Red-headed Vulture } \\
\text { Sarcogyps calvus }\end{array}$ & CR & w, 3 & $\begin{array}{l}\text { Around habitation, open } \\
\text { country }\end{array}$ \\
\hline $\begin{array}{l}\text { 10. Greater Spotted Eagle } \\
\text { Aquila clanga }\end{array}$ & VU & w, 4 & $\begin{array}{l}\text { Large rivers and lakes, wooded } \\
\text { areas near water }\end{array}$ \\
\hline $\begin{array}{l}\text { 11. Indian Spotted Eagle } \\
\text { Aquila hastata }\end{array}$ & VU & r3 & Open country, grassland \\
\hline $\begin{array}{l}\text { 12. Lesser Kestrel } \\
\text { Falco naumanni }\end{array}$ & VU & w m 4 & Open country \\
\hline $\begin{array}{l}\text { 13. Lesser Adjutant } \\
\text { Leptoptilos javanicus }\end{array}$ & VU & br 2 & Marshes, pools, grassland \\
\hline $\begin{array}{l}\text { 14. Hodgson's Bushchat } \\
\text { Saxicola insignis }\end{array}$ & VU & w2 & Grassland \\
\hline $\begin{array}{l}\text { 15. Bristled Grassbird } \\
\text { Chaetornis striatus }\end{array}$ & VU & $\mathrm{s}, \mathrm{r} ? 2$ & Grassland \\
\hline $\begin{array}{l}\text { 16. Jerdon's Babbler } \\
\text { Chrysomma altirostre }\end{array}$ & VU & r5 & Wet grassland \\
\hline $\begin{array}{l}\text { 17. Finn's Weaver } \\
\text { Ploceus megarhynchus }\end{array}$ & VU & br2 & Grassland \\
\hline $\begin{array}{l}\text { 18. Yellow-breasted Bunting } \\
\text { Emberiza aureola }\end{array}$ & VU & w3 & Grassland \\
\hline
\end{tabular}


H.S. Baral and C. Inskipp/ Our Nature (2009) 7: 56-81

\section{Globally near-threatened birds}

Table 2. Globally near-threatened birds recorded in Sukla Phanta, Nepal

\begin{tabular}{|c|c|c|}
\hline Species name & $\begin{array}{l}\text { Status in Sukla } \\
\text { Phanta }\end{array}$ & Habitat \\
\hline $\begin{array}{l}\text { 1. Falcated Duck } \\
\text { Anas falcata }\end{array}$ & w, 4 & Lakes \\
\hline $\begin{array}{l}\text { 2. Ferruginous Pochard } \\
\text { Aythya nyroca }\end{array}$ & $\mathrm{w}, 3$ & Lakes and large rivers \\
\hline $\begin{array}{l}\text { 3. Great Hornbill } \\
\text { Buceros bicornis }\end{array}$ & $\mathrm{m} ?, 5$ & Dense forest \\
\hline $\begin{array}{l}\text { 4. Eurasian Curlew } \\
\text { Numenius arquatus }\end{array}$ & $\mathrm{m}, 4$ & Rivers \\
\hline $\begin{array}{l}\text { 5. Black-bellied Tern } \\
\text { Sterna acuticauda }\end{array}$ & r?5 & Marshes, lakes and rivers \\
\hline $\begin{array}{l}\text { 6. Lesser Fish Eagle } \\
\text { Ichthyophaga humilis }\end{array}$ & r? 5 & Forested streams and lakes \\
\hline $\begin{array}{l}\text { 7. Grey-headed Fish Eagle } \\
\text { Ichthyophaga ichthyaetus }\end{array}$ & br2 & $\begin{array}{l}\text { Slow-running waters and lakes in } \\
\text { wooded country }\end{array}$ \\
\hline $\begin{array}{l}\text { 8. Pallid Harrier } \\
\text { Circus macronous }\end{array}$ & w, 4 & Open grassland \\
\hline $\begin{array}{l}\text { 9. Darter } \\
\text { Anhinga melanogaster }\end{array}$ & br2 & $\begin{array}{l}\text { Lakes, pools and slow moving } \\
\text { rivers }\end{array}$ \\
\hline $\begin{array}{l}\text { 10. Painted Stork } \\
\text { Mycteria leucocephala }\end{array}$ & $\mathrm{s}, \mathrm{r} ?, 4$ & Marshes and lakes \\
\hline $\begin{array}{l}\text { 11. Black-necked Stork } \\
\text { Ephippiorhynchus asiaticus }\end{array}$ & $\mathrm{w}, \mathrm{r} ?, 4$ & Lakers, marshes and large rivers \\
\hline $\begin{array}{l}\text { 12. Black-headed Ibis } \\
\text { Threskiornis melanocephalus }\end{array}$ & w?, 4 & $\begin{array}{l}\text { Marshes, lakes, open fields and } \\
\text { Rivers }\end{array}$ \\
\hline $\begin{array}{l}\text { 13. Rufous-rumped Grassbird } \\
\text { Graminicola bengalensis }\end{array}$ & br1 & Grassland \\
\hline
\end{tabular}

$\mathrm{Br}=$ breeding resident, $\mathrm{r}=$ resident, $\mathrm{s}=$ summer visitor, $\mathrm{w}=$ winter visitor, $\mathrm{m}=$ passage migrant, $1=$ common, $2=$ fairly common, $3=$ frequent, $4=$ uncommon, $5=$ rare

grasslands. Comb Duck Sarkidiornis melanotos was listed as resident by Schaaf et al. (1980) and up to 20 were seen at Rani Tal in May 1982 (Inskipp and Inskipp, 1982), and 25 birds in January 2009 (Hathan Chaudhary verbally, 2009).

Shikari Tal is little visited by ornithologists. In May 1996 a large breeding colony of four species was discovered here: Cattle Egret Bubulcus ibis (3,000+ nests), Little Cormorant Phalacrocorax niger (150+ nests), Great Egret Egretta alba and Intermediate Egret Egretta intermedia (33+ nests). Other birds seen included a Darter and two immature Painted Storks (Baral, 1996b).

\section{Forest birds}

Sukla Phanta's sal and riverine forests are of less interest ornithologically than the reserve's grasslands and wetlands. The forests generally have a poorly developed understorey and their bird diversity is reduced as a result. A few nationally threatened birds do however depend on forests: Spot-bellied Eagle Owl Bubo nipalensis which has been proved breeding, Dusky Eagle Owl Bubo coromandus, 
Rufous-bellied Eagle Hiaeratus kienerii and Oriental Pied Hornbill Anthracoceros albirostris (Baral and Inskipp, 2004). The forests are also important for Great Slaty Woodpecker Mulleripicus pulverulentus, the largest living species of woodpecker in the old world and White-naped Woodpecker Chrysocolaptes festivus.

\section{Other wildlife}

A total of 30 species of mammals has been recorded on the reserve Globally threatened mammals include the Tiger Panthera tigris, Swamp Deer Cervus duvauceli duvauceli, Asian Elephant Elephas maximus, the recently introduced Greater One-horned Rhinoceros Rhinoceros unicornis and Hispid Hare Caprolagus hispidus which are all resident (IUCN, 2009) The congregation of this subspecies of Swamp Deer on the reserve's phantas is the largest in the world (Schaaf, 1978). The reserve had been well known for its good population of Tigers and at one time supported the highest density in Nepal, although the population has been much reduced by poaching in recent years. Sukla Phanta's population of Hispid Hare may be of international significance (Bell, 1986). Large reptiles include the Indian Rock Python Python molurus and Marsh Mugger Crocodylus palustris (Bhatt and Shrestha, 1977) both globally threatened (IUCN, 2009). The total of 27 fish species has been recorded in rivers, lakes and ponds of the reserve (Bhatt and Shrestha, 1977). Not much is known about the herpetofauna of the reserve.

\section{Threats}

\section{Grasslands}

Grassland encroachment by tree and shrub saplings were identified as major threats to the long-term existence of the main phantas by Baral et al. (2003), Inskipp and Inskipp (1983) and Poudyal et al. (2008a). There is a tendency to encourage people to plant trees in heavily-grazed grasslands as a step towards reforestation. Such activities reduce the grassland area considerably. As they grow, the trees out compete any grasses growing under them, especially those that need plenty of sunlight. Tree seeds are dispersed all over the grasslands and generally germinate near already existing trees. In the long run a small patch of trees that is created in grassland may eventually take over all the grassland area. Additionally, trees encourage the growth of shade-loving grasses and inhibit growth of sun-loving species. This process of succession usually converts grassland into woodland over time (Baral, 2001).

With the exception of the main phanta many grasslands on the reserve are overgrazed, notably those lying close to human settlements e.g. grasslands close to Jhilmila (Baral, 1997d). During the first author's stay in Sukla Phanta in 1996-1997 he noted more than 50 buffaloes daily in Dudhiya Phanta and the number hiked to more than 100 in May 1997. In May 1996 some 15 to 20 livestock were seen grazing daily in Singhpur Phanta (Baral, 1997d). Tamang and Baral (2000) describe Haraiya Phanta and Karaiya Phanta as overgrazed and were of the opinion that if this trend continues it is likely that the few Bengal Floricans present on these grasslands would disappear soon. The continuing degradation of the reserve's grasslands can be partly attributed to lack of patrolling and lack of initiatives by the army guards and park administrators. Grazing pressure from domestic livestock has been the major factor causing the decline of many grassland animals that are now threatened (Baral, 
1997d). Although such overgrazed grasslands provide habitat for many common bird species, many threatened species are absent (Baral, 2001).

There is a high density on the phantas of Jackal Canis aureus and Wild Boar Sus scrofa, both of which are predators of eggs and chicks (Baral et al., 2003).

\section{Wetlands}

The three lakes are all choked with aquatic vegetation. This appears to be of native vegetation at Rani Tal, but the whole of Shikari Tal was covered in the invasive introduced Eichhornia crassipes (Baral, 1996b). Most of Salghaudi Tal is now covered with Phragmites karka reeds and a very small area of open water is left. In April 2001 less than $10 \%$ of the water at Rani Tal remained open in contrast to 1982 when a considerable water area was free of surface vegetation. In early May 1982 six wildfowl species including Comb Duck and Cotton Pygmy-goose Nettapus coromandelianus, as well as 12 wader species including Greater Painted-snipe Rostratula benghalensis and the rare passage migrant Long-toed Stint Calidris subminuta were seen here. By comparison, habitats for ducks and waders were much reduced in April 2001 (Inskipp and Inskipp, 2001). The lake had been regularly managed by clearing aquatic vegetation, but this has been neglected in recent years (Hari Krishna Shrestha verbally, 2001).

\section{Forests}

Sukla Phanta's forests are highly susceptible to fires that are lit deliberately and sometimes accidentally. Fire encourages the growth of new shoots of grasses and also kills some trees which villagers tend to collect for using firewood. While fires benefit ungulates by encouraging a fresh growth of grasses, they have much reduced shrub and tree regeneration and resulted in open forests with little or no understorey and a much reduced bird community. It is notable that no laughing thrushes have been recorded at Sukla Phanta and only three other forest babblers. This group depends on a good forest shrub layer.

\section{Lack of awareness}

Many army guards, park rangers and game scouts were unaware of Nepal's protected species and of threatened species that occur on the reserve (Baral, 1997d). Tamang and Baral (2000) reported that most game scouts, elephant caretakers and local people did not have any knowledge about Bengal Floricans. Few game scouts and elephant caretakers had a chance to gain some knowledge about this bird or to see it in the wild. An army guard post was established in Sukla Phanta proper so the guards could be in a better position to protect the reserves' wildlife from poachers. The location of the guard post is in a sensitive area for many globally threatened species, some of which are vulnerable to disturbance.

\section{Conservation measures \\ Wetland management}

Appropriate and regular management, especially regular clearing of surface aquatic vegetation could restore the lakes. Some work was carried out at Rani Tal in 1998 and was supported by the reserve authority and assisted by help from the Silent Safari Camp and Bird Conservation Nepal. This included making an earthen embankment over $600 \mathrm{~m}$ long and $3 \mathrm{~m}$ high to trap a larger quantity of monsoon rain and so significantly raise the water level of the lake (Bisht, 1998). 


\section{Grassland management}

Inskipp and Inskipp (1983) reported that villagers cut grasses in the main phanta annually in winter. The phanta is then divided into four sections where are burned separately to ensure that some grassland is always available for grazing.

The use of controlled fires seems essential to maintain the grassland ecosystem (Baral, 2001). Controlled cutting and prescribed burning should be carried out before March every year as later fires can be harmful to young birds (Inskipp and Inskipp, 1983). Bengal Florican researchers in India found that unless burning, clearing or grazing of grassland takes place, the grassland grows too tall and dense for the species and is apparently vacated by territorial males (Narayan and Rosalind, 1990). Controlled cutting and burning can benefit other bird species. Swamp Francolin, doves and pigeons benefit temporarily from cutting as they have been frequently noted feeding in the clearings close to tall grasslands (Baral, 2001). Large areas of burnt open grasslands are ideal for species hunting insects in the air and small animals on the ground. Drongos, stonechats, swallows, owls, bee-eaters, rollers, Whitethroated Kingfisher Halcyon smyrnensis, Jungle Myna Acridotheres fuscus, Darkthroated Thrush Turdus ruficollis, Ashy Swallow-shrike Artamus fuscus and Longtailed Shrike Lanius schach have all been observed to feed in these areas (Baral, 2001).

Poudyal et al. (2008a, b) report that the Suklaphanta Wildlife Reserve Authority undertook restoration work on the main phanta in 2007, uprooting and removing bushes and trees to prevent succession to scrub/forest. Two territorial male Bengal Floricans were observed by Poudyal et al. (2008b) on these newly managed grassland patches where bushes and trees had been removed. Maintaining this practice in the future will be necessary in order to main the grassland habitat for this species.

In order to conserve Bengal Floricans, maintaining interspersed small patches of taller grasses on the shorter grassland dominated by Imperata cylindrica is crucial and should be made the objective of grassland management activities such as burning and cutting. Preventing succession from Imperata grassland to tall grassland is vital (Poudyal et al., 2008b).

Whatever the management regimes may be, cutting, burning or grazing, all directly affect the height of grasses (Baral, 2001) and the thickness. These are important parameters that influence bird communities. Some bird species that have adapted to living in grasslands have become highly specialized. Examples include Pale-footed Bush-warbler Cettia pallidipes and Greycrowned Prinia Prinia cinereocapilla both of which prefer Themeda grasslands. Others include Hodgson's Bushchat and Bengal Florican which require large expanses of open phantas. Jerdon's Bushchat and Striated Grassbird need tall Phragmites karka and Saccharum arundinacea grass species. Bristled Grassbird prefers Sachharum spontaneum grasslands that grow along the river courses (Baral, 2001). All species mentioned above and a number of nationally threatened specices that also depend on lowland grasslands require further research and investigation that is useful for their long-term conservation.

Knowledge about Sukla Phanta's threatened species and internationally and nationally important habitats needs to disseminate in a relevant and sensitive way to inspire army and reserve staff and local 
people to take a pride in the reserve and safeguard its future.

Aided by UNDP technical advice and financial assistance the Western Terai Landscape Complex Project (2006-2012) aims to establish a landscape-level management model to safeguard the area's biological wealth and its vital ecological functions. The project is promoting landscape level conservation across the two protected areas, Sukla Phanta Wildlife Reserve and Bardiya National Park, their buffer zones and adjoining landscapes in 52 VDCs of Bardiya, Kailali and Kanchanpur districts. Achievements so far include establishing 530 hectares of plantations in 45 forest corridors and critical buffer-zone areas close to the two protected areas. Ecoclubs in 62 schools have been set up by the project (UNDP, 2009).

The National Trust for Nature Conservation (NTNC) has been conducting several activities on various thematic programmes in Sukla Phanta Wildlife Reserve to conserve its biodiversity. These programmes include a natural resource conservation programme carried out through community mobilisation and support, an alternative energy promotion programme aimed at reducing dependency on fuel wood consumption, a conservation education and extension programme to increase awareness amongst the public, a sustainable community development programme to strengthen community participation, a biodiversity research and monitoring programme on prey and predator species, and community health service support to improve health of local communities (NTNC, 2008). The biodiversity research and monitoring programme is mainly focused on large mammals although the field office aims to include some nationally threatened bird species in future (Chiranjivi Pokharel verbally 2008; Hemant Yadav verbally 2009).

\section{Acknowledgements}

The authors would like to thank former Director Generals of Department of National Parks and Wildlife Conservation, Dr Uday Raj Sharma, late Dr Tirtha Man Maskey, Dr Swoyambhu Man Amatya, late Narayan Paudel, Shyam Bajimaya and also Gopal Upadhyay, the current Director General for granting permission to study birds of the reserve. In Suklaphanta, Chief Warden Gopal Upadhyay, Puran Bhakta Shrestha, Tika Ram Adhikari, Acting Chief Wardens Babu Ram Yadav, Sher Singh Thagunna and Uba Raj Regmi for their cooperation and support. For logistics and support, we would like to thank Col Hikmat Bisht and Peter Byrne (Silent Safari Camp) and Sukla Phanta Wildlife Camp. We would also like to thank Suchit Basnet, Tika Ram Giri, Hathan Chaudhary, Hem Subedi, Basu Bindari, Bishnu Mahato, Som GC, Dev Raj Joshi and Eswar Raj Pant for sharing their valuable bird records with us.

\section{References}

Baral, H.S. 1991. A checklist of birds recorded at Suklaphanta Wildlife Reserve, March 1991. (Unpublished)

Baral, H.S. 1995a. A checklist of birds recorded at Suklaphanta Wildife Reserve, January 1995. (Unpublished)

Baral, H.S. 1995b. Black-necked Stork endangered. Newsletter for Birdwatchers 35(4): 74-75.

Baral, H.S. 1996a. A list of birds recorded at Suklaphanta Wildlife Reserve. 7-19 May 1996. (Unpublished)

Baral, H.S. 1996b. An introduction to Shikari Tal, Sukila Phanta Wild life Reserve. Bird Conservation Nepal Newsletter 5(2): 4-5. 


\section{H.S. Baral and C. Inskipp/ Our Nature (2009) 7: 56-81}

Baral, H.S. 1997a. A checklist of birds recorded at Suklaphanta Wild life Reserve. 21 Dec 1996-18 Jan 1997. (Unpublished)

Baral, H.S. 1997b. A checklist of bird recorded at Suklaphanta Wild life Reserve, May, November and December 1997. (Unpublished)

Baral, H.S. 1997c. Bristled Grassbird Chaetornis striatus in Nepal. Danphe 6 (2): 5-6.

Baral, H.S. 1997d. Sukla Phanta: a grassland reserve of international importance. Danphe 6 (3): 6-8.

Baral, H.S. 1998a. A checklist of birds recorded at Suklaphanata Wildlife Reserve. March and May 1998. (Unpublished)

Baral, H.S. 1998b. Finn's Weaver Ploceus megarhynchus and Singing Bushlark Mirafra cantillans: two new species for Nepal. Forktail 13: 129-130.

Baral, H.S. 1998c. Status, distribution and habitat preferences of Swamp Francolin Francolinus gularis in Nepal. Ibisbill 1: 35-70.

Baral, H.S. 1998d. Hodgson's Bushchat Saxicola insignis Gray and Gray 1846 in Nepal. Report to Department of National Parks and Wildlife Conservation (HMG, Nepal), Biodiversity Support Program (USA) and Oriental Bird Club (UK). (Unpublished)

Baral, H.S. 1999. Hodgson's Bushchat in Nepal. Oriental Bird Club Bulletin 30: 15-16.

Baral, H.S. 2000. Notes on distribution of some grassland birds in Nepal with reference to Sukla Phanta. Danphe 9(3): 6-7.

Baral, H.S. 2001. Community structure and habitat associations of lowland grassland birds in Nepal. University of Amsterdam, Amsterdam, The Netherlands. (Ph.D. Thesis, Unpublished)

Baral, H.S. 2007. A checklist of birds seen between Delhi/Naini Tal to Chitwan/Phulchoki, April 2007. (Unpublished)

Baral, H.S. 2009. A checklist of birds recorded at Suklaphanta Wildlife Reserve December 2008February and April 2009. (Unpublished)

Baral, H.S. and C. Inskipp 2004. The state of Nepal's birds 2004. Department of National Parks and Wildlife Conservation, Bird Conservation Nepal and IUCN Nepal, Kathmandu, Nepal.

Baral, H.S. and C. Inskipp 2005. Important Bird Areas in Nepal: key sites for conservation. Bird
Conservation Nepal and Bird Life International, Kathmandu and Cambridge.

Baral, H.S. and D. Mills 1992. A checklist of birds recorded during lowland Nepal tour. (Unpublished)

Baral, H.S., E.R. Pant and D.R. Joshi 2008. First breeding record of Finn's Weaver Ploceus megarhynchus in Nepal. Danphe 17(2): 5-6.

Baral, N., N. Timilsina and B. Tamang 2003. Status of Bengal Florican Houbaropsis bengalensis in Nepal. Forktail 19: 51-55.

Bell, D. 1986. A Study of the Hispid hare Caprolagus hispidus in Royal Suklaphanta Wildlife Reserve, western Nepal: A Summary Report. Dodo, Journal of the Jersey Wildlife Preservation Trust 23: 24-31.

Bhatt, D.D. and T.K. Shrestha 1977. The environment of Sukla Phanta. Tribhuvan University, Kathmandu, Nepal.

Bird Life International 2009. Birds on the IUCN Red List. http://www.birdlife.org/action/science/ species/global_species_programme/red_list.html Accessed 1 November 2009.

Bisht, H.B. 1998. Restoration of Rani Tal. Danphe 7(1-2): 5 .

Chaudhary, H. 1997. Additional Sightings. Danphe 6(1): 2-3.

Choudhary, H. 1996. Additional Sightings. Danphe 5(2): 2-3.

GC, S. 1999. A list of birds recorded in Sukla Phanta Wildlife Reserve between 1998-1999. (Unpublished)

Giri, J.B. and S. GC 2005. Survey of nesting vultures in Royal Suklaphanta Wildlife Reserve, west Nepal. Birding Asia 3: 9.

Giri, T. 1998. Additional sightings! Danphe 7(1-2): 1112.

Giri, T. and H. Choudhary 1997. Additional Sightings. Danphe 6(2): 7-8.

Giri, T. and H. Choudhary 1998. Additional sightings! Danphe 7(3-4): 2.

Giri, T. and H. Choudhary 2001. Additional sightings! Danphe 10(1-2): 2.

Giri, T. and H. Choudhary 2008. Additional sightings! Danphe 17(2): 7 .

Inskipp, C. 1989. Nepal's forest birds: their status and conservation. Cambridge, UK: International Council for Bird Preservation. Monograph No. 4. 


\section{H.S. Baral and C. Inskipp/ Our Nature (2009) 7: 56-81}

Inskipp, C. and T. Inskipp 1983. Report on a Survey of Bengal Floricans (Houbaropsis bengalensis) in Nepal and India, 1982. Cambridge, UK: International Council for Bird Preservation (Study Report 2).

Inskipp, C. and T. Inskipp 2001. A re-visit to Nepal's lowland protected areas. Danphe 10(1-2): 4-7.

IUCN 2009. IUCN Red List. http://www.iucnred list.org/Accessed 1 November 2009.

Narayan, G. and L. Rosalind 1990. An introduction to the Bengal Florican. In Status and ecology of the Lesser and Bengal Floricans, with reports on Jerdon's Courser and Mountain Quail. Bombay Natural History Society, Mumbai. Pp.9-16.

NTNC 2008. Annual Report 2008. National Trust for Nature Conservation (NTNC), Jawalakhel, Lalitpur, Nepal.

Oaks, J.L., M. Gilbert, M.Z. Virani, R.T. Watson, C.U. Meteyer, B. Rideout, H.L. Shivaprasad, S. Ahmed, M.J.I. Chaudhry, M. Arshad, S. Mahmood, A. Ali and A.A. Khan 2004. Diclofenac residues as the cause of vulture population decline in Pakistan. Nature 427: 630-633.

Poudyal, L.P., P.B. Singh and S. Maharajan 2008c. The decline of Bengal Florican Hourbaropsis bengalensis in Nepal. Danphe 17(1): 4-6. http://www.bird lifenepal.org/news letter/danfe _mar_08.pdf

Poudyal, L.P., P.B. Singh and S. Maharjan 2008a. Status and distribution of Bengal Florican Houbaropsis bengalensis in Nepal, 2007. Report to the Oriental Bird Club, UK and the Club 300 Foundation for Bird Protection, Sweden. Kathmandu, Nepal: Department of National Parks and Wild life Conservation, and Bird Conservation Nepal.

Poudyal, L.P., P.B. Singh and S. Maharjan 2008b. Bengal Florican Houbaropsos bengalensis in Nepal: an update. Birding Asia 10: 43-47.

Schaaf, D. 1978. Population size and structure and habitat relations of the barasingha (Cervus duvauceli) in Sukla Phanta Wildlife Reserve, Nepal. Michigan State University. 111p. (Ph.D. Thesis, Unpublished)

Schaaf, D., C.G. Rice, R.L.Sr. Fleming and R.L.Jr. Fleming 1980. A partial checklist of the birds of Sukla Phanta Wildlife Reserve, Nepal, with remarks on the relevance of species inventories. (Unpublished)

Sharma, S. 2005a. Population status and distribution of Lesser Adjutant Stork Leptoptilos javanicus in far western lowland (Bardia, Kailai and Kanchanpur Districts), Nepal. Report to Oriental Bird Club. (Unpublished)

Sharma, S. 2005b. Population status and distribution of Lesser Adjutant Leptoptilus javanicus in Bardia, Kailai and Kanchanpur districts, western Nepal. Birding Asia 3: 8.

Sharma, S. 2006. Population status and distribution of Lesser Adjutant (Leptoptilos javanicus) in farwestern lowland Nepal. Tigerpaper 33(4): 9-11. http://www.fao.org/world/regional/rap/ tigerpaper/Paper/TP33_4_001.pdf

Singh, P.B. 2004. Population status and habitat utilisation of Swamp Francolin in Royal Sukla Phanta Wildlife Reserve, Nepal. Birding Asia 2: 83.

Tamang, B. and N. Baral 2000. Population status and distribution of Bengal Floricans Houbaropsis bengalensis in the Royal Suklaphanta Wildlife Reserve, Nepal. Report to Oriental Bird Club. (Unpublished)

UNDP 2009. Western Terai Landscape Complex Project. http://www.undp.org.np/energy/projects/ WTLCP/index.php?ProgramID=37 Accessed 1 November 2009.

Weaver, D.J. 1991. A survey of Bengal Floricans (Houbaropsis bengalensis) at Royal Suklaphanta Wildlife Reserve and Royal Bardia National Park, western Nepal, 1990. Report to Oriental Bird Club. (Unpublished)

WWF Nepal 2000. WWF in Nepal. Three decades of partnership in conservation (1967-2000). Kathmandu. 
H.S. Baral and C. Inskipp/ Our Nature (2009) 7: 56-81

Appendix. A checklist of birds recorded at Sukila Phanta Wildlife Reserve, Nepal

\begin{tabular}{|c|c|c|c|}
\hline Order/Family/English Name & Scientific Name & Status & References \\
\hline \multicolumn{4}{|l|}{ GALLIFORMES } \\
\hline \multicolumn{4}{|l|}{ Phasianidae } \\
\hline Black Francolin & Francolinus francolinus & br, 1 & Inskipp 1989 \\
\hline Grey Francolin & Francolinus pondicerianus & $\mathrm{r}, 4$ & $\begin{array}{l}\text { Subedi and Shrestha 2003, Tika Giri } \\
\text { verbally } 2009\end{array}$ \\
\hline Swamp Francolin & Francolinus gularis & br, 2 & Inskipp 1989 \\
\hline Common Quail & Coturnix coturnix & $\mathrm{w}, \mathrm{m}, 5$ & $\begin{array}{l}\text { Bhatt and Shrestha 1977, Inskipp } \\
1989\end{array}$ \\
\hline Blue-breasted Quail & Coturnix chinensis & r?, 5 & Baral 1996a \\
\hline Red Junglefowl & Gallus gallus & br, 1 & Inskipp 1989 \\
\hline Kalij Pheasant & Lophura leucomelanos & $\mathrm{r}, 3$ & Subedi and Shrestha 2003 \\
\hline Indian Peafowl & Pavo cristatus & br, 1 & Inskipp 1989 \\
\hline \multicolumn{4}{|l|}{ ANSERIFORMES } \\
\hline \multicolumn{4}{|l|}{ Dendrocygnidae } \\
\hline Lesser Whistling Duck & Dendrocygna javanica & br, 2 & Inskipp 1989 \\
\hline \multicolumn{4}{|l|}{ Anatidae } \\
\hline Bar-headed Goose & Anser indicus & $\mathrm{m}, 3$ & Inskipp 1989 \\
\hline Ruddy Shelduck & Tadorna ferruginea & $\mathrm{w}, 2$ & Inskipp 1989 \\
\hline Comb Duck & Sarkidiornis melanotos & $\mathrm{r}, 3$ & Inskipp 1989 \\
\hline Cotton Pygmy-goose & Nettapus coromandelianus & $\mathrm{r}, \mathrm{s}, 2$ & Inskipp 1989 \\
\hline Gadwall & Anas strepera & $\mathrm{w}, 1$ & Inskipp 1989 \\
\hline Falcated Duck & Anas falcata & $\mathrm{w}, 4$ & Baral 1995a \\
\hline Eurasian Wigeon & Anas penelope & $\mathrm{w}, 2$ & Baral 1997a \\
\hline Mallard & Anas platyrhynchos & $\mathrm{w}, 2$ & Inskipp 1989 \\
\hline Spot-billed Duck & Anas poecilorhyncha & $\mathrm{w}, 4$ & Inskipp 1989 \\
\hline Northern Shoveler & Anas clypeata & $\mathrm{w}, 3$ & GC 1999 \\
\hline Northern Pintail & Anas acuta & $\mathrm{w}, 2$ & Inskipp 1989 \\
\hline Garganey & Anas querquedula & $\mathrm{w}, \mathrm{m}, 3$ & Inskipp 1989 \\
\hline Common Teal & Anas crecca & $\mathrm{w}, 1$ & Baral 1997a \\
\hline Red-crested Pochard & Rhodonessa rufina & w, 3 & Inskipp 1989 \\
\hline Common Pochard & Aythya ferina & $\mathrm{w}, 2$ & Inskipp 1989 \\
\hline Ferruginous Pochard & Aythya nyroca & w, 3 & Inskipp 1989 \\
\hline Tufted Duck & Aythya fuligula & $\mathrm{w}, 3$ & Baral and Mills 1992 \\
\hline Common Merganser & Mergus merganser & $\mathrm{w}, 3$ & Subedi and Shrestha 2003 \\
\hline \multicolumn{4}{|l|}{ TURNICIFORMES } \\
\hline \multicolumn{4}{|l|}{ Turnicidae } \\
\hline Small Buttonquail & Turnix sylvatica & r? & Subedi and Shrestha 2003 \\
\hline Yellow-legged Buttonquail & Turnix tanki & $\mathrm{r} ?$ & Baral Pers Obs. \\
\hline Barred Buttonquail & Turnix suscitator & $\mathrm{r}, 4$ & Inskipp 1989 \\
\hline
\end{tabular}


H.S. Baral and C. Inskipp/ Our Nature (2009) 7: 56-81

PICIFORMES
Picidae
Eurasian Wryneck
Brown-capped Pygmy
Woodpecker
Grey-capped Pygmy
Woodpecker
Fulvous-breasted
Woodpecker
Yellow-crowned
Woodpecker
Rufous Woodpecker
Lesser Yellownape
Greater Yellownape
Streak-throated
Woodpecker
Grey-headed Woodpecker
Himalayan Flameback
Black-rumped Flameback
Greater Flameback
White-naped Woodpecker
Bay Woodpecker
Great Slaty Woodpecker
Megalaimidae
Brown-headed Barbet
Lineated Barbet
Blue-throated Barbet
Coppersmith Barbet

\section{BUCEROTIFORMES}

\section{Bucerotidae}

Indian Grey Hornbill

Oriental Pied Hornbill

Great Hornbill

\section{UPUPIFORMES}

Upupidae

Common Hoopoe

\section{CORACIIFORMES}

Coraciidae

Indian Roller

Dollarbird

Alcedinidae

Common Kingfisher

Blue-eared Kingfisher

Dacelonidae

Jynx torquilla
Dendrocopos nanus
Dendrocopos canicapillus
Dendrocopos macei
Dendrocopos mahrattensis
Celeus brachyurus
Picus chlorolophus
Picus flavinucha
Picus xanthopygaeus
Picus canus
Dinopium shorii
Dinopium benghalense
Chrysocolaptes lucidus
Chrysocolaptes festivus
Blythipicus pyrrhotis
Mulleripicus pulverulentus
Megalaima zeylanica
Megalaima lineata
Megalaima asiatica
Megalaima haemacephala

w, 3

br, $1 \quad$ Inskipp 1989

r, 4 Subedi and Shrestha 2003

r, 3 Dev Raj Joshi verbally 2009, Hathan Chaudhary 2009

r, $3 \quad$ Inskipp 1989

r, $3 \quad$ Inskipp 1989

$\mathrm{r}, 2$

r?, 4

br, 1

br, 2

br, 2

br, 1

br, 2

br, 3

v? w? 5

br, 3

br, 1

br, 4

r?, 4

br, 2

Dev Raj Joshi verbally 2009

Dev Raj Joshi verbally 2009

Inskipp 1989

Inskipp 1989

Inskipp 1989

Inskipp 1989

Inskipp 1989

Inskipp 1989

Inskipp 1989

Inskipp 1989

Ocyceros birostris

Anthracoceros albirostris

Buceros bicornis

br, 2

Inskipp 1989

br, $1 \quad$ Inskipp 1989

m?, $5 \quad$ Baral 1997a

w, m, 2 Inskipp 1989

Upupa epops

Coracias benghalensis

Eurystomus orientalis

br, 1

Inskipp 1989

bs

Inskipp 1989

Alcedo atthis

Alcedo meninting

br, 1

Inskipp 1989

r?, 5 Inskipp and Inskipp 1991 
H.S. Baral and C. Inskipp/ Our Nature (2009) 7: 56-81

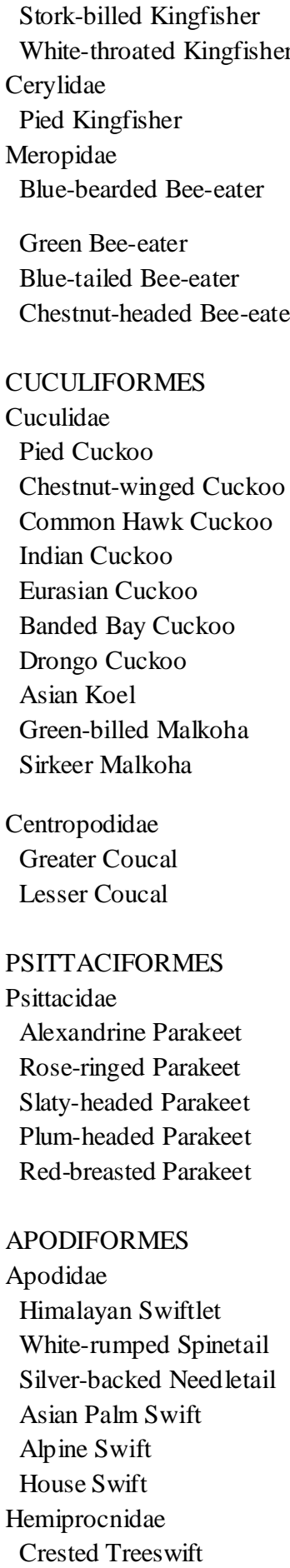

Pelargopsis capensis

Halcyon smyrnensis

Ceryle rudis

Nyctyornis athertoni

Merops orientalis

Merops philippinus

Merops leschenaulti

\begin{tabular}{|c|c|}
\hline br, 2 & Inskipp 1989 \\
\hline br, 1 & Inskipp 1989 \\
\hline br, 2 & Inskipp 1989 \\
\hline $\mathrm{r}, 4$ & $\begin{array}{l}\text { Baral 1991, Subedi and Shrestha } \\
2003\end{array}$ \\
\hline br, s, 2 & Inskipp 1989 \\
\hline bs, 2 & Inskipp 1989 \\
\hline bs, 3 & Baral 1991, Baral 1996a \\
\hline
\end{tabular}

bs, $4 \quad$ Inskipp 1989

bs, $4 \quad$ Dev Raj Joshi verbally 2009

br, $1 \quad$ Inskipp 1989

bs, $1 \quad$ Inskipp 1989

bs, 2 Inskipp 1989

r?, $5 \quad$ GC 1999

bs, 3 Baral 1996a

bs, $2 \quad$ Inskipp 1989

br, $4 \quad$ GC 1999

br, 2 Inskipp 1989

br, $1 \quad$ Inskipp 1989

bs, r, $2 \quad$ Inskipp 1989

Psittacula eupatria

Psittacula krameri

Psittacula himalayana

Psittacula cyanocephala

Psittacula alexandri

$\begin{array}{ll}\text { br, 1 } & \text { Inskipp 1989 } \\ \text { br, 1 } & \text { Inskipp 1989 } \\ \text { w, 4 } & \text { Chaudhary 1997 } \\ \text { br, 1 } & \text { Inskipp 1989 } \\ \text { r, 4 } & \text { Inskipp 1989 }\end{array}$

Collocalia brevirostris

Zoonavena sylvatica

$\begin{array}{ll}\text { w, 3 } & \text { Baral 1997a } \\ \text { r, 3 } & \text { Inskipp 1989 }\end{array}$

Hirundapus cochinchinensis

Cypsiurus balasiensis

s?, 4

Subedi and Shrestha 2003

Tachymarptis melba

r?, 4

w, 3

r, 3

Subedi and Shrestha 2003

Apus affinis

Inskipp 1989

Inskipp 1989

Hemiprocne coronata

Inskipp 1989 
H.S. Baral and C. Inskipp/ Our Nature (2009) 7: 56-81

\section{STRIGIFORMES}

Tytonidae

Grass Owl

Strigidae

Oriental Scops Owl

Collared Scops Owl

Eurasian Eagle Owl

Spot-bellied Eagle Owl

Dusky Eagle Owl

Brown Fish Owl

Asian Barred Owlet

Jungle Owlet

Spotted Owlet

Brown Hawk-Owl

Caprimulgidae

Large-tailed Nightjar

Indian Nightjar

Savanna Nightjar

\section{COLUMBIFORMES}

Columbidae

Rock Pigeon
Oriental Turtle Dove

Spotted Dove

Red Collared Dove

Eurasian Collared Dove

Emerald Dove

Orange-breasted Green

Pigeon

Pompadour Green Pigeon

Yellow-footed Green

Pigeon

\section{GRUIFORMES}

Otididae

Bengal Florican

Lesser Florican

Gruidae

Sarus Crane

Demoiselle Crane

Rallidae

Brown Crake

White-breasted Waterhen

Ruddy-breasted Crake

Tyto capensis
Otus sunia
Otus bakkamoena
Bubo bubo
Bubo nipalensis
Bubo coromandus
Ketupa zeylonensis
Glaucidium cuculoides
Glaucidium radiatum
Athene brama
Ninox scutulata
Caprimulgus macrurus
Caprimulgus asiaticus
Caprimulgus affinis

r?, $5 \quad$ Inskipp 1989

r, 2 Inskipp 1989

r, 2 Inskipp 1989

r, 4 Baral 1997b, Subedi and Shrestha 2003

br, $4 \quad$ Giri 1997

br, $3 \quad$ Giri and Choudhary 1997

br, 2 Inskipp 1989

r, $5 \quad$ Inskipp 1989

br, $1 \quad$ Inskipp 1989

br, 2 Inskipp 1989

br, $2 \quad$ Inskipp 1989

r, $2 \quad$ Inskipp 1989

r?, $4 \quad$ Inskipp 1989

s?, $2 \quad$ Inskipp 1989

\section{Columba livia}

Streptopelia orientalis

Streptopelia chinensis

Streptopelia tranquebarica

Streptopelia decaocto

Chalcophaps indica

Treron bicincta

Treron pompadora

Treron phoenicoptera

$\begin{array}{ll}\text { br, 2 } & \text { Inskipp 1989 } \\ \text { w, 2 } & \text { Inskipp 1989 } \\ \text { br, 1 } & \text { Inskipp 1989 } \\ \text { br, 2 } & \text { Inskipp 1989 } \\ \text { br, 1 } & \text { Inskipp 1989 } \\ \text { br, 1 } & \text { Inskipp 1989 } \\ \text { r, 3 } & \text { Inskipp 1989 } \\ \text { r, 3 } & \text { Chaudhary 1997 } \\ \text { r, 2 } & \text { Inskipp 1989 }\end{array}$

r, $2 \quad$ Inskipp 1989

$\begin{array}{lll}\begin{array}{l}\text { Houbaropsis bengalensis } \\ \text { Sypheotides indica }\end{array} & \text { bs, 2 } & \text { Inskipp } 1989 \\ \text { sC } 5 & \text { GC } 1999 \\ \begin{array}{l}\text { Grus antigone } \\ \text { Grus virgo }\end{array} & \begin{array}{l}\text { s, r?, } 4 \\ \text { m, } 5\end{array} & \begin{array}{l}\text { Inskipp 1989 } \\ \text { Inskipp 1989 }\end{array} \\ \text { Amaurornis akool } & \text { br, 5 } & \begin{array}{l}\text { Subedi and Shrestha 2003, Hathan } \\ \text { Chaudhary 2009 }\end{array} \\ \begin{array}{l}\text { Amaurornis phoenicurus } \\ \text { Porzana fusca }\end{array} & \text { br, 1 } & \begin{array}{l}\text { Insipp 1989 } \\ \text { Inskipp 1989 }\end{array}\end{array}$


H.S. Baral and C. Inskipp/ Our Nature (2009) 7: 56-81

Watercock

Purple Swamphen

Common Moorhen

Common Coot

\section{CICONIIFORMES}

Scolopacidae

Pintail Snipe

Common Snipe

Eurasian Curlew

Spotted Redshank

Common Redshank

Marsh Sandpiper

Common Greenshank

Green Sandpiper

Wood Sandpiper

Common Sandpiper

Little Stint

Temminck's Stint

Long-toed Stint

Ruff

Rostratulidae

Greater Painted-snipe

Jacanidae

Pheasant-tailed Jacana

Bronze-winged Jacana

Burhinidae

Eurasian Thick-knee

Great Thick-knee

Charadriidae

Black-winged Stilt

Little Ringed Plover

Kentish Plover

Lesser Sand Plover

Northern Lapwing

Yellow-wattled Lapwing

River Lapwing

Red-wattled Lapwing

Glareolidae

Indian Courser

Oriental Pratincole

Small Pratincole

Laridae

Pallas's Gull

Brown-headed Gull
Gallicrex cinerea

Porphyrio porphyrio

Gallinula chloropus

Fulica atra

br, 2

w, 1

w, 2

Dev Raj Joshi verbally 2009

Inskipp 1989

Inskipp 1989

Inskipp 1989

\section{Gallinago stenura}

Gallinago gallinago

Numenius arquata

Tringa erythropus

Tringa totanus

Tringa stagnatilis

Tringa nebularia

Tringa ochropus

Tringa glareola

Actitis hypoleucos

Calidris minuta

Calidris temminckii

Calidris subminuta

Philomachus pugnax

Rostratula benghalensis

Hydrophasianus chirurgus

Metopidius indicus

Burhinus oedicnemus

Esacus recurvirostris

Himantopus himantopus

Charadrius dubius

Charadrius alexandrinus

Charadrius mongolus

Vanellus vanellus

Vanellus malarbaricus

Vanellus duvaucelii

Vanellus indicus

Cursorius coromandelicus

Glareola maldivarum

Glareola lactea

Larus ichthyaetus

Larus brunnicephalus w, 3

$\mathrm{w}, 2$

m, 4

m, 4

w, 3

$\mathrm{m}, 4$

w, 1

w, 1

w, 2

w, 1

w, 4

w, 2

w, 5

m, 4

r, 3

r, s, 3

br, 2

r, 3

r, 5

m, 5

r?, w, 2

w, 4

$\mathrm{m}, 5$

w, m, 3

r, 3

br, 2

br, 1

w, r?, 5

s, 5

r, 3

w, 3

w, 4
Subedi and Shrestha 2003, Hathan Chaudhary 2009

Inskipp 1989

Bhatt and Shrestha 1977

Inskipp 1989

Baral 1998a

Inskipp 1989

Inskipp 1989

Inskipp 1989

Inskipp 1989

Inskipp 1989

Hathan Chaudhary 2009

Baral 1997b

Inskipp 1989

Inskipp 1989

Inskipp 1989

Inskipp 1989

Inskipp 1989

Inskipp 1989

Subedi and Shrestha 2003

Inskipp 1989

Inskipp 1989

Hathan Chaudhary 2009

Subedi and Shrestha 2003

Baral 1997a

Inskipp 1989

Inskipp 1989

Inskipp 1989

Giri and Choudhary 1997

Choudhary 1996

Inskipp 1989

Hathan Chaudhary 2009

Tika Giri verbally 2009 
H.S. Baral and C. Inskipp/ Our Nature (2009) 7: 56-81

\begin{tabular}{|c|c|c|c|}
\hline River Tern & Sterna aurantia & $\mathrm{r}, 5$ & Inskipp 1989 \\
\hline Little Tern & Sterna albifrons & $\mathrm{s}, 4$ & Subedi and Shrestha 2003 \\
\hline Black-bellied Tern & Sterna acuticauda & $\mathrm{r} ?, 5$ & Inskipp 1989 \\
\hline \multicolumn{4}{|l|}{ Accipitridae } \\
\hline Osprey & Pandion haliaetus & w, 3 & Inskipp 1989 \\
\hline Oriental Honey-buzzard & Pernis ptilorhyncus & $\mathrm{r}, 1$ & Inskipp 1989 \\
\hline Black-shouldered Kite & Elanus caeruleus & $\mathrm{r}, \mathrm{w} ?, 2$ & Inskipp 1989 \\
\hline Black Kite & Milvus migrans & $\mathrm{w}, \mathrm{r}, 2$ & Inskipp 1989 \\
\hline Brahminy Kite & Haliastur indus & $\mathrm{w}, 5$ & Inskipp 1989 \\
\hline Pallas's Fish Eagle & Haliaeetus leucoryphus & br?, w, 5 & Inskipp 1989 \\
\hline Lesser Fish Eagle & Ichthyophaga humilis & r?, 5 & Inskipp 1989 \\
\hline Grey-headed Fish Eagle & Ichthyophaga ichthyaetus & br, 2 & Inskipp 1989 \\
\hline Egyptian Vulture & Neophron percnopterus & $\mathrm{w}, \mathrm{r} ?, 3$ & Inskipp 1989 \\
\hline White-rumped Vulture & Gyps bengalensis & br, 3 & Inskipp 1989 \\
\hline Slender-billed Vulture & Gyps tenuirostris & br, 3 & Inskipp 1989 \\
\hline Himalayan Griffon & Gyps himalayensis & $\mathrm{w}, 2$ & Baral 1997a \\
\hline Eurasian Griffon & Gyps fulvus & w, m, 4 & Inskipp 1989 \\
\hline Cinereous Vulture & Aegypius monachus & $\mathrm{w}, 4$ & Baral and Mills 1992 \\
\hline Red-headed Vulture & Sarcogyps calvus & w, 3 & Inskipp 1989 \\
\hline Short-toed Snake Eagle & Circaetus gallicus & w, 3 & Baral 1997b \\
\hline Crested Serpent Eagle & Spilornis cheela & br, 1 & Inskipp 1989 \\
\hline Eurasian Marsh Harrier & Circus aeruginosus & w, 2 & Inskipp 1989 \\
\hline Hen Harrier & Circus cyaneus & $\mathrm{w}, 2$ & Inskipp 1989 \\
\hline Pallid Harrier & Circus macrourus & w, 4 & Baral 1997b \\
\hline Pied Harrier & Circus melanoleucos & w, 4 & Inskipp 1989 \\
\hline Montagu's Harrier & Circus pygargus & w, 5 & Chaudhary 1997 \\
\hline Shikra & Accipiter badius & br, 1 & Inskipp 1989 \\
\hline Besra & Accipiter virgatus & $\mathrm{r} ?, 3$ & Chaudhary 1997 \\
\hline Eurasian Sparrowhawk & Accipiter nisus & $\mathrm{w}, 4$ & Subedi and Shrestha 2003 \\
\hline White-eyed Buzzard & Butastur teesa & $\mathrm{r}, 2$ & Inskipp 1989 \\
\hline Common Buzzard & Buteo buteo & w, 3 & Baral 1997b \\
\hline Long-legged Buzzard & Buteo rufinus & w, 3 & Subedi and Shrestha 2003 \\
\hline Indian Spotted Eagle & Aquila hastata & $\mathrm{r}, 3$ & Baral 1997b \\
\hline Greater Spotted Eagle & Aquila clanga & w, 4 & Baral 1995a \\
\hline Tawny Eagle & Aquila rapax & $\mathrm{r}, 5$ & Inskipp 1989 \\
\hline Steppe Eagle & Aquila nipalensis & w, 3 & Baral 1997b \\
\hline Bonelli's Eagle & Hieraaetus fasciatus & w, 4 & Giri 1998 \\
\hline Booted Eagle & Hieraaetus pennatus & w, 3 & Inskipp 1989 \\
\hline Rufous-bellied Eagle & Hieraaetus kienerii & w, 4 & Baral 2009 \\
\hline Changeable Hawk Eagle & Spizaetus cirrhatus & $\mathrm{r}, 2$ & Inskipp 1989 \\
\hline Mountain Hawk Eagle & Spizaetus nipalensis & w, 4 & Subedi and Shrestha 2003 \\
\hline \multicolumn{4}{|l|}{ Falconidae } \\
\hline Collared Falconet & Microhierax caerulescens & w?, 5 & GC 1999 \\
\hline Lesser Kestrel & Falco naumanni & w, m, 4 & Baral Pers Obs. \\
\hline Common Kestrel & Falco tinnunculus & w, 3 & Baral 1997ab \\
\hline
\end{tabular}


H.S. Baral and C. Inskipp/ Our Nature (2009) 7: 56-81

\begin{tabular}{|c|c|c|c|}
\hline Red-necked Falcon & Falco chiquera & r?, 4 & Subedi and Shrestha 2003 \\
\hline Eurasian Hobby & Falco subbuteo & $\mathrm{s}, 4$ & Giri and Choudhary 1997 \\
\hline Peregrine Falcon & Falco peregrinus & $\mathrm{w}, 4$ & Baral 1996a \\
\hline \multicolumn{4}{|l|}{ Podicipedidae } \\
\hline Little Grebe & Tachybaptus ruficollis & r, w?, 3 & Inskipp 1989 \\
\hline Great Crested Grebe & Podiceps cristatus & $\mathrm{w}, 4$ & Subedi and Shrestha 2003 \\
\hline \multicolumn{4}{|l|}{ Anhingidae } \\
\hline Oriental Darter & Anhinga melanogaster & br, 2 & Inskipp 1989 \\
\hline \multicolumn{4}{|l|}{ Phalacrocoracidae } \\
\hline Little Cormorant & Phalacrocorax niger & br, 1 & Inskipp 1989 \\
\hline Great Cormorant & Phalacrocorax carbo & $\mathrm{w}, 2$ & Inskipp 1989 \\
\hline \multicolumn{4}{|l|}{ Ardeidae } \\
\hline Little Egret & Egretta garzetta & $\mathrm{br}, 1$ & Inskipp 1989 \\
\hline Grey Heron & Ardea cinerea & $\mathrm{w}, 3$ & Inskipp 1989 \\
\hline Purple Heron & Ardea purpurea & br, 1 & Inskipp 1989 \\
\hline Great Egret & Casmerodius albus & br, 2 & Inskipp 1989 \\
\hline Intermediate Egret & Mesophoyx intermedia & br, 2 & Inskipp 1989 \\
\hline Cattle Egret & Bubulcus ibis & br, 1 & Inskipp 1989 \\
\hline Indian Pond Heron & Ardeola grayii & br, 1 & Inskipp 1989 \\
\hline Little Heron & Butorides striatus & $\mathrm{r}, 2$ & Inskipp 1989 \\
\hline Black-crowned Night & Nycticorax nycticorax & br, 3 & Inskipp 1989 \\
\hline \multicolumn{4}{|l|}{ Heron } \\
\hline Yellow Bittern & Ixobrychus sinensis & bs, r, 3 & GC 1999 \\
\hline Cinnamon Bittern & Ixobrychus cinnamomeus & $\mathrm{bs}, \mathrm{r}, 3$ & Inskipp 1989 \\
\hline Black Bittern & Dupetor flavicollis & br, 4 & Inskipp 1989 \\
\hline \multicolumn{4}{|l|}{ Threskiornithidae } \\
\hline Black-headed Ibis & Threskiornis melanocephalus & w?, 4 & $\begin{array}{l}\text { Dev Raj Joshi verbally 2009, Hathan } \\
\text { Chaudhary } 2009\end{array}$ \\
\hline Black Ib is & Pseudibis papillosa & br, 2 & Inskipp 1989 \\
\hline Eurasian Spoonbill & Platalea leucorodia & $\mathrm{m}, 5$ & Baral 1995a \\
\hline \multicolumn{4}{|l|}{ Ciconiidae } \\
\hline Painted Stork & Mycteria leucocephala & $\mathrm{s}, \mathrm{r} ?, 4$ & Inskipp 1989 \\
\hline Asian Openbill & Anastomus oscitans & $\mathrm{r}, 3$ & Inskipp 1989 \\
\hline Black Stork & Ciconia nigra & $\mathrm{w}, 3$ & Baral 1997b \\
\hline Woolly-necked Stork & Ciconia episcopus & $\mathrm{r}, 2$ & Inskipp 1989 \\
\hline White Stork & Ciconia ciconia & $\mathrm{m}, 5$ & GC 1999 \\
\hline Black-necked Stork & Ephippiorhynchus asiaticus & $\mathrm{w}, \mathrm{r} ?, 4$ & Inskipp 1989 \\
\hline Lesser Adjutant & Leptoptilos javanicus & br, 2 & Inskipp 1989 \\
\hline \multicolumn{4}{|l|}{ PASSERIFORMES } \\
\hline \multicolumn{4}{|l|}{ Pittidae } \\
\hline Indian Pitta & Pitta brachyura & $\mathrm{bs}, \mathrm{r}, 3$ & Inskipp 1989 \\
\hline \multicolumn{4}{|l|}{ Irenidae } \\
\hline Golden-fronted Leafbird & Chloropsis aurifrons & $\mathrm{r}, 3$ & Inskipp 1989 \\
\hline \multicolumn{4}{|l|}{ Laniidae } \\
\hline Brown Shrike & Lanius cristatus & $\mathrm{w}, 3$ & GC 1999 \\
\hline
\end{tabular}


H.S. Baral and C. Inskipp/ Our Nature (2009) 7: 56-81

\begin{tabular}{|c|c|c|c|}
\hline Bay-backed Shrike & Lanius vittatus & $\mathrm{m}, 4$ & Giri 1998 \\
\hline Long-tailed Shrike & Lanius schach & br, 1 & Inskipp 1989 \\
\hline Grey-backed Shrike & Lanius tephronotus & $\mathrm{w}, 3$ & Inskipp 1989 \\
\hline \multicolumn{4}{|l|}{ Corvidae } \\
\hline Red-billed Blue Magpie & Urocissa erythrorhyncha & r?, 4 & Baral 1997a \\
\hline Rufous Treepie & Dendrocitta vagabunda & br, 1 & Inskipp 1989 \\
\hline House Crow & Corvus splendens & br, 2 & Inskipp 1989 \\
\hline Large-billed Crow & Corvus macrorhynchos & br, 1 & Inskipp 1989 \\
\hline Ashy Woodswallow & Artamus fuscus & $\mathrm{r}, 3$ & GC 1999 \\
\hline Eurasian Golden Oriole & Oriolus oriolus & bs, 3 & Inskipp 1989 \\
\hline Black-hooded Oriole & Oriolus xanthornus & br, 1 & Inskipp 1989 \\
\hline Large Cuckooshrike & Coracina macei & br, 1 & Inskipp 1989 \\
\hline Black-winged & Coracina melaschistos & br, 3 & Inskipp 1989 \\
\hline Cuckooshrike & & & \\
\hline Black-headed & Coracina melanoptera & s, 4 & Subedi and Shrestha 2003 \\
\hline \multicolumn{4}{|l|}{ Cuckooshrike } \\
\hline Rosy Minivet & Pericrocotus roseus & s, 4 & $\begin{array}{l}\text { Tika Giri verbally 2009, Subedi and } \\
\text { Shrestha } 2003\end{array}$ \\
\hline Small Minivet & Pericrocotus cinnamomeus & br, 1 & Inskipp 1989 \\
\hline Long-tailed Minivet & Pericrocotus ethologus & $\mathrm{w}, 2$ & Inskipp 1989 \\
\hline Scarlet Minivet & Pericrocotus flammeus & br, 2 & Inskipp 1989 \\
\hline $\begin{array}{l}\text { Bar-winged Flycatcher- } \\
\text { shrike }\end{array}$ & Hemipus picatus & br, 2 & Inskipp 1989 \\
\hline Yellow-bellied Fantail & Rhipidura hypoxantha & $\mathrm{w}, 3$ & $\begin{array}{l}\text { Baral and Mills 1992, Chaudhary } \\
1997\end{array}$ \\
\hline White-throated Fantail & Rhipidura albicollis & br, 2 & Inskipp 1989 \\
\hline White-browed Fantail & Rhipidura aureola & br, 4 & Inskipp 1989 \\
\hline Black Drongo & Dicrurus macrocercus & br, 1 & Inskipp 1989 \\
\hline Ashy Drongo & Dicrurus leucophaeus & $\mathrm{r}, 2$ & GC 1999 \\
\hline White-bellied Drongo & Dicrurus caerulescens & br, 1 & Inskipp 1989 \\
\hline Crow-bellied Drongo & Dicrurus annectans & s, 4 & $\begin{array}{l}\text { Baral 1997b, Subedi and Shrestha } \\
2003\end{array}$ \\
\hline $\begin{array}{l}\text { Lesser Racket-tailed } \\
\text { Drongo }\end{array}$ & Dicrurus remifer & w, 4 & Giri 1998 \\
\hline Spangled Drongo & Dicrurus hottentottus & br, 2 & Inskipp 1989 \\
\hline Greater Racket-tailed & Dicrurus paradiseus & $\mathrm{br}, 1$ & Inskipp 1989 \\
\hline \multicolumn{4}{|l|}{ Drongo } \\
\hline Black-naped Monarch & Hypothymis azurea & bs, 3 & Inskipp 1989 \\
\hline Asian Paradise-flycatcher & Terpsiphone paradisi & bs, 3 & Inskipp 1989 \\
\hline Common Iora & Aegithina tiphia & br, 1 & Inskipp 1989 \\
\hline Large Woodshrike & Tephrodornis gularis & r?, 4 & $\begin{array}{l}\text { Subedi and Shrestha 2003, Dev Raj } \\
\text { Joshi verbally } 2009\end{array}$ \\
\hline Common Woodshrike & Tephrodornis pondicerianus & br, 2 & Baral 1997a \\
\hline \multicolumn{4}{|l|}{ Muscicapidae } \\
\hline Blue-capped Rock Thrush & Monticola cinclorhynchus & $\mathrm{m}, 4$ & $\begin{array}{l}\text { Subedi and Shrestha 2003, Tika Giri } \\
\text { verbally } 2009\end{array}$ \\
\hline Blue Rock Thrush & Monticola solitarius & $\mathrm{w}, 3$ & Subedi and Shrestha 2003 \\
\hline Blue Whistling Thrush & Myophonus caeruleus & $\mathrm{w}, 3$ & Inskipp 1989 \\
\hline Orange-headed Thrush & Zoothera citrina & bs, 2 & Inskipp 1989 \\
\hline
\end{tabular}


H.S. Baral and C. Inskipp/ Our Nature (2009) 7: 56-81

Scaly Thrush

Tickell's Thrush

Dark-throated Thrush

Dark-sided Flycatcher

Asian Brown Flycatcher

Rusty-tailed Flycatcher

Rufous-gorgeted Flycatcher

Red-throated Flycatcher

Snowy-browed Flycatcher

Little Pied Flycatcher

Ultramarine Flycatcher

Slaty-blue Flycatcher

Verditer Flycatcher

Pale-chinned Flycatcher

Blue-throated Flycatcher

Tickell's Blue Flycatcher

Grey-headed Canary

Flycatcher

Siberian Rubythroat

White-tailed Rubythroat

Bluethroat

Oriental Magpie Robin

White-rumped Shama

Indian Robin

Black Redstart

White-capped Water

Redstart

Black-backed Forktail

Hodgson's Bushchat

Common Stonechat

White-tailed Stonechat

Pied Bushchat

Jerdon's Bushchat

Grey Bushchat

Variable Wheatear

Sturnidae

Spot-winged Starling

Chestnut-tailed Starling

Brahminy Starling

Common Starling

Asian Pied Starling

Common Myna

Bank Myna

Jungle Myna

Hill Myna

\section{Zoothera dauma \\ Turdus unicolor \\ Turdus ruficollis \\ Muscicapa sibirica \\ Muscicapa dauurica \\ Muscicapa ruficauda \\ Ficedula strophiata \\ Ficedula parva \\ Ficedula hyperythra \\ Ficedula westermanni \\ Ficedula superciliaris \\ Ficedula tricolor \\ Eumyias thalassina \\ Cyornis poliogenys \\ Cyornis rubeculoides \\ Cyornis tickelliae \\ Culicicapa ceylonensis}

Luscinia calliope

Luscinia pectoralis

Luscinia svecica

Copsychus saularis

Copsychus malabaricus

Saxicoloides fulicata

Phoenicurus ochruros

Chaimarrornis

leucocephalus

Enicurus immaculatus

Saxicola insignis

Saxicola torquata

Saxicola leucura

Saxicola caprata

Saxicola jerdoni

Saxicola ferrea

Oenanthe picata

Saroglossa spiloptera

Sturnus malabaricus

Sturnus pagodarum

Sturnus vulgaris

Sturnus contra

Acridotheres tristis

Acridotheres ginginianus

Acridotheres fuscus

Gracula religiosa

\begin{tabular}{|c|c|}
\hline $\mathrm{w}, 3$ & Baral 1995a \\
\hline $\mathrm{w}, 3$ & Inskipp 1989 \\
\hline $\mathrm{w}, 3$ & Inskipp 1989 \\
\hline $\mathrm{m}, 4$ & Baral Pers Obs. \\
\hline $\mathrm{m}, 4$ & Subedi and Shrestha 2003 \\
\hline w, 4 & Inskipp 1989 \\
\hline w, 4 & $\begin{array}{l}\text { Baral and Mills 1992, Chaudhary } \\
1997\end{array}$ \\
\hline w, 2 & Baral 1991 \\
\hline w, 5 & Baral and Mills 1992 \\
\hline w, 5 & Inskipp 1989 \\
\hline w, 5 & Giri 1998 \\
\hline $\mathrm{w}, 2$ & Inskipp 1989 \\
\hline w, 3 & Baral 1991 \\
\hline br, 4 & Baral 1996a \\
\hline w?, 4 & Baral 1997a \\
\hline br, 3 & Inskipp 1989 \\
\hline $\mathrm{w}, 2$ & Inskipp 1989 \\
\hline $\mathrm{w}, 4$ & Inskipp 1989 \\
\hline $\mathrm{w}, 3$ & Baral 1997a \\
\hline $\mathrm{w}, 1$ & Inskipp 1989 \\
\hline br, 1 & Inskipp 1989 \\
\hline br, 2 & Inskipp 1989 \\
\hline br, 3 & Inskipp 1989 \\
\hline $\mathrm{w}, \mathrm{m}, 3$ & Baral and Mills 1992 \\
\hline $\mathrm{w}, 4$ & Subedi and Shrestha 2003 \\
\hline $\mathrm{r}, 3$ & Subedi and Shrestha 2003 \\
\hline $\mathrm{w}, 2$ & Baral and Mills 1992 \\
\hline $\mathrm{w}, 1$ & Inskipp 1989 \\
\hline br, 1 & Inskipp 1989 \\
\hline br, 1 & Inskipp 1989 \\
\hline br, 3 & Choudhary 1996 \\
\hline $\mathrm{w}, 2$ & Inskipp 1989 \\
\hline $\mathrm{m}, 5$ & Giri 1998 \\
\hline $\mathrm{w}, 3$ & Giri 1998 \\
\hline br, 2 & Inskipp 1989 \\
\hline br, 3 & Inskipp 1989 \\
\hline $\mathrm{w}, \mathrm{m}, 2$ & Inskipp 1989 \\
\hline br, 1 & Inskipp 1989 \\
\hline br, 1 & Inskipp 1989 \\
\hline br, 1 & Inskipp 1989 \\
\hline br, 1 & Inskipp 1989 \\
\hline br, 4 & Dev Raj Joshi verbally 2009 \\
\hline
\end{tabular}


H.S. Baral and C. Inskipp/ Our Nature (2009) 7: 56-81

Sittidae

\begin{tabular}{|c|c|c|c|}
\hline Chestnut-bellied Nuthatch & Sitta castanea & br, 1 & Inskipp 1989 \\
\hline Velvet-fronted Nuthatch & Sitta frontalis & r?, 5 & Baral and Mills 1992 \\
\hline \multicolumn{4}{|l|}{ Paridae } \\
\hline Great Tit & Parus major & br, 1 & Inskipp 1989 \\
\hline \multicolumn{4}{|l|}{ Hirundinidae } \\
\hline Sand Martin & Riparia riparia & $\mathrm{m}, 4$ & Subedi and Shrestha 2003 \\
\hline Pale Martin & Riparia diluta & $\mathrm{s}, \mathrm{r} ?, 3$ & Giri and Choudhary 1997 \\
\hline Plain Martin & Riparia paludicola & br, 1 & Inskipp 1989 \\
\hline Barn Swallow & Hirundo rustica & $\mathrm{r}, \mathrm{w}, 1$ & Inskipp 1989 \\
\hline Red-rumped Swallow & Hirundo daurica & $\mathrm{r}, 2$ & Inskipp 1989 \\
\hline Streak-throated Swallow & Hirundo fluvicola & $\mathrm{s}, \mathrm{r} ?, 3$ & $\begin{array}{l}\text { Choudhary 1996, Giri and } \\
\text { Choudhary } 1997\end{array}$ \\
\hline Northern House Martin & Delichon urbica & w?, 5 & Subedi and Shrestha 2003 \\
\hline Asian House Martin & Delichon dasypus & w, 5 & Giri 1998 \\
\hline Nepal House Martin & Delichon nipalensis & w, 4 & Inskipp 1989 \\
\hline \multicolumn{4}{|l|}{ Pycnonotidae } \\
\hline Black-crested Bulbul & Pycnonotus melanicterus & $\mathrm{r}, 3$ & Inskipp 1989 \\
\hline Himalayan Bulbul & Pycnonotus leucogenys & $\mathrm{r}, 3$ & Bhatt and Shrestha 1977 \\
\hline Red-whiskered Bulbul & Pycnonotus jocosus & br, 1 & Inskipp 1989 \\
\hline Red-vented Bulbul & Pycnonotus cafer & br, 1 & Inskipp 1989 \\
\hline Black Bulbul & Hypsipetes leucocephalus & $\mathrm{w}, 4$ & Dev Raj Joshi verbally 2009 \\
\hline \multicolumn{4}{|l|}{ Cisticolidae } \\
\hline Zitting Cisticola & Cisticola juncidis & br, 1 & Inskipp 1989 \\
\hline Bright-capped Cisticola & Cisticola exilis & br, 2 & Inskipp 1989 \\
\hline Grey-breasted Prinia & Prinia hodgsonii & br, 1 & Inskipp 1989 \\
\hline Graceful Prinia & Prinia gracilis & br, 3 & Baral 1997b \\
\hline Jungle Prinia & Prinia sylvatica & br, 3 & Inskipp 1989 \\
\hline Yellow-bellied Prinia & Prinia flaviventris & br, 2 & Inskipp 1989 \\
\hline Ashy Prinia & Prinia socialis & br, 1 & Inskipp 1989 \\
\hline Plain Prinia & Prinia inornata & br, 1 & Inskipp 1989 \\
\hline \multicolumn{4}{|l|}{ Zosteropidae } \\
\hline Oriental White-eye & Zosterops palpebrosus & br, 1 & Inskipp 1989 \\
\hline \multicolumn{4}{|l|}{ Sylviidae } \\
\hline Grey-bellied Tesia & Tesia cyaniventer & w, 5 & Baral Pers Obs. \\
\hline Pale-footed Bush Warbler & Cettia pallidipes & $\mathrm{r} ?, 5$ & $\begin{array}{l}\text { Inskipp 1989, Subedi and Shrestha } \\
2003\end{array}$ \\
\hline \multicolumn{3}{|l|}{ Warbler } & Baral 2007 \\
\hline Aberrant Bush Warbler & Cettia flavolivacea & $\mathrm{w}, 1$ & $\begin{array}{l}\text { Baral and Mills 1992, Chaudhary } \\
1997\end{array}$ \\
\hline Grey-sided Bush Warbler & Cettia brunnifrons & $\mathrm{w}, 2$ & Baral 1995a, Chaudhary 1997 \\
\hline Spotted Bush Warbler & Bradypterus thoracicus & w, 3 & Inskipp 1989 \\
\hline Lanceolated Warbler & Locustella lanceolata & $\mathrm{m}, 4$ & Inskipp 1989 \\
\hline Grasshopper Warbler & Locustella naevia & $\mathrm{m}, 5$ & Inskipp and Inskipp 2001 \\
\hline Paddyfield Warbler & Acrocephalus agricola & $\mathrm{w}, \mathrm{m}, 4$ & Baral 1997b \\
\hline Blyth's Reed Warbler & Acrocephalus dumetorum & $\mathrm{w}, 1$ & Inskipp 1989 \\
\hline
\end{tabular}


H.S. Baral and C. Inskipp/ Our Nature (2009) 7: 56-81

\begin{tabular}{|c|c|c|c|}
\hline Clamorous Reed Warbler & Acrocephalus stentoreus & $\mathrm{w}, 3$ & Baral 1997b \\
\hline Thick-billed Warbler & Acrocephalus aedon & $\mathrm{w}, 4$ & Chaudhary 1997 \\
\hline Moustached Warbler & Acrocephalus melanopogon & $\mathrm{m}, 5$ & Baral et al. 2002 \\
\hline Booted Warbler & Hippolais caligata & $\mathrm{w}, 3$ & Baral 1997ab \\
\hline Common Tailorbird & Orthotomus sutorius & br, 1 & Inskipp 1989 \\
\hline Common Chiffchaff & Phylloscopus collybita & $\mathrm{w}, \mathrm{m}, 2$ & Inskipp 1989 \\
\hline Dusky Warbler & Phylloscopus fuscatus & $\mathrm{w}, \mathrm{m}, 3$ & Inskipp 1989 \\
\hline Smoky Warbler & Phylloscopus fuligiventer & $\mathrm{w}, 2$ & Inskipp 1989 \\
\hline Tickell's Leaf Warbler & Phylloscopus affinis & $\mathrm{w}, \mathrm{m}, 3$ & Inskipp 1989 \\
\hline Sulphur-bellied Warbler & Phylloscopus griseolus & $\mathrm{m}, 4$ & Baral Pers Obs. \\
\hline Lemon-rumped Warbler & Phylloscopus chloronotus & $\mathrm{w}, 3$ & Inskipp 1989 \\
\hline Yellow-browed Warbler & Phylloscopus inornatus & $\mathrm{w} ?, \mathrm{~m}, 5$ & Tika Giri verbally 2009 \\
\hline Hume's Warbler & Phylloscopus humei & $\mathrm{w}, 1$ & Inskipp 1989 \\
\hline Large-billed Leaf Warbler & Phylloscopus magnirostris & $\mathrm{m}, 5$ & Subedi and Shrestha 2003 \\
\hline Greenish Warbler & Phylloscopus trochiloides & $\mathrm{w}, 2$ & Inskipp 1989 \\
\hline Western Crowned Warbler & Phylloscopus occipitalis & $\mathrm{m}, 5$ & $\begin{array}{l}\text { Inskipp and Inskipp 2001, Subedi } \\
\text { and Shrestha } 2003\end{array}$ \\
\hline Blyth's Leaf Warbler & Phylloscopus reguloides & $\mathrm{w}, 2$ & Inskipp 1989 \\
\hline Golden-spectacled Warbler & Seicercus burkii & $\mathrm{w}, 2$ & Inskipp 1989 \\
\hline Whistler's Warbler & Seicercus whistleri & $\mathrm{w}, 2$ & Subedi and Shrestha 2003 \\
\hline Grey-hooded Warbler & Seicercus xanthoschistos & $\mathrm{w}, 3$ & Inskipp 1989 \\
\hline Striated Grassbird & Megalurus palustris & br, 2 & Inskipp 1989 \\
\hline Bristled Grassbird & Chaetornis striatus & $\mathrm{s}, \mathrm{r} ?, 2$ & Baral 1997c \\
\hline Rufous-rumped Grassbird & Graminicola bengalensis & br, 1 & Inskipp 1989 \\
\hline Puff-throated Babbler & Pellorneum ruficeps & $\mathrm{r}, 5$ & GC 1999 \\
\hline Tawny-bellied Babbler & Dumetia hyperythra & $\mathrm{r}, 3$ & Baral 1996a \\
\hline Striped Tit Babbler & Macronous gularis & $\mathrm{r}, 3$ & Inskipp 1989 \\
\hline Chestnut-capped Babbler & Timalia pileata & br, 1 & Inskipp 1989 \\
\hline Yellow-eyed Babbler & Chrysomma sinense & $\mathrm{br}, 2$ & Inskipp 1989 \\
\hline Jerdon's Babbler & Chrysomma altirostre & $\mathrm{r}, 5$ & Giri 1998, Inskipp and Inskipp 2001 \\
\hline Common Babbler & Turdoides caudatus & r?, 5 & Bhatt and Shrestha 1977 \\
\hline Striated Babbler & Turdoides earlei & br, 1 & Inskipp 1989 \\
\hline Jungle Babbler & Turdoides striatus & br, 1 & Inskipp 1989 \\
\hline White-bellied Yuhina & Yuhina zantholeuca & w?, 5 & $\begin{array}{l}\text { Baral and Mills 1992, Chaudhary } \\
1997\end{array}$ \\
\hline Lesser Whitethroat & Sylvia curruca & $\mathrm{m}, 5$ & Baral Pers Obs. \\
\hline Orphean Warbler & Sylvia hortensis & $\mathrm{m}, 4$ & Inskipp 1989 \\
\hline \multicolumn{4}{|l|}{ Alaudidae } \\
\hline Singing Lark & Mirafra cantillans & $\mathrm{s}, \mathrm{r} ?, 4$ & Baral 1998b \\
\hline Rufous-winged Lark & Mirafra assamica & br, 2 & Inskipp 1989 \\
\hline Ashy-crowned Sparrow & Eremopterix grisea & br, 2 & Inskipp 1989 \\
\hline \multicolumn{4}{|l|}{ Lark } \\
\hline Rufous-tailed Lark & Ammomanes phoenicurus & w?, r? 5 & Giri 1998 \\
\hline Sand Lark & Calandrella raytal & br, 1 & GC 1999 \\
\hline Crested Lark & Galerida cristata & $\mathrm{r}, 4$ & Subedi and Shrestha 2003 \\
\hline Oriental Skylark & Alauda gulgula & $\mathrm{br}, 1$ & Inskipp 1989 \\
\hline
\end{tabular}


H.S. Baral and C. Inskipp/ Our Nature (2009) 7: 56-81

\begin{tabular}{|c|c|c|c|}
\hline \multicolumn{4}{|l|}{ Nectariniidae } \\
\hline Thick-billed Flowerpecker & Dicaeum agile & $\mathrm{r}, 2$ & Inskipp 1989 \\
\hline Pale-billed Flowerpecker & Dicaeum erythrorynchos & $\mathrm{r}, 3$ & Inskipp 1989 \\
\hline Purple Sunbird & Nectarinia asiatica & br, 1 & Inskipp 1989 \\
\hline Green-tailed Sunbird & Aethopyga nipalensis & $\mathrm{w}, 4$ & Bhatt and Shrestha 1977 \\
\hline Crimson Sunbird & Aethopyga siparaja & $\mathrm{r}, 4$ & Inskipp 1989 \\
\hline Streaked Spiderhunter & Arachnothera magna & r?, 5 & Subedi and Shrestha 2003 \\
\hline \multicolumn{4}{|l|}{ Passeridae } \\
\hline House Sparrow & Passer domesticus & br, 3 & Inskipp 1989 \\
\hline Eurasian Tree Sparrow & Passer montanus & $\mathrm{r}, 4$ & \\
\hline Chestnut-shouldered & Petronia xanthocollis & br, 1 & Inskipp 1989 \\
\hline \multicolumn{4}{|l|}{ Petronia } \\
\hline White Wagtail & Motacilla alba & $\mathrm{w}, 1$ & Inskipp 1989 \\
\hline White-browed Wagtail & Motacilla maderaspatensis & br, 2 & Inskipp 1989 \\
\hline Citrine Wagtail & Motacilla citreola & w, m, 2 & Inskipp 1989 \\
\hline Yellow Wagtail & Motacilla flava & w, m, 3 & Inskipp 1989 \\
\hline Grey Wagtail & Motacilla cinerea & w, 3 & Inskipp 1989 \\
\hline Richard's Pipit & Anthus richardi & $\mathrm{w}, 2$ & Inskipp 1989 \\
\hline Paddyfield Pipit & Anthus rufulus & br, 1 & Baral 1997a \\
\hline Tawny Pipit & Anthus campestris & $\mathrm{w}, 4$ & Baral 1997a \\
\hline Blyth's Pipit & Anthus godlewskii & w, 4 & Baral 1995a \\
\hline Long-billed Pipit & Anthus similis & w, 3 & Baral and Mills 1992 \\
\hline Tree Pipit & Anthus trivialis & w, m, 4 & Baral 1997a \\
\hline Olive-backed Pipit & Anthus hodgsoni & w, 2 & Inskipp 1989 \\
\hline Red-throated Pipit & Anthus cervinus & w?, 5 & Baral 1997b \\
\hline Rosy Pipit & Anthus roseatus & $\mathrm{w}, 2$ & Baral 1997b \\
\hline Black-breasted Weaver & Ploceus benghalensis & $\mathrm{r}, 1$ & Inskipp 1989 \\
\hline Streaked Weaver & Ploceus manyar & r?, 4 & Inskipp 1989 \\
\hline Baya Weaver & Ploceus philippinus & $\mathrm{r}, 1$ & Inskipp 1989 \\
\hline Finn's Weaver & Ploceus megarhynchus & br, 2 & Baral 1998b \\
\hline Red Avadavat & Amandava amandava & br, 2 & Inskipp 1989 \\
\hline Scaly-breasted Munia & Lonchura punctulata & br, 2 & Inskipp 1989 \\
\hline Black-headed Munia & Lonchura malacca & $\mathrm{r}, 4$ & Baral 1997b \\
\hline \multicolumn{4}{|l|}{ Fringillidae } \\
\hline \multirow{2}{*}{\multicolumn{4}{|c|}{ Greenfinch }} \\
\hline & & & \\
\hline Common Rosefinch & Carpodacus erythrinus & $\mathrm{w}, 2$ & Inskipp 1989 \\
\hline Crested Bunting & Melophus lathami & w, 2 & Inskipp 1989 \\
\hline Chestnut-eared Bunting & Emberiza fucata & w, 3 & Chaudhary 1997 \\
\hline Yellow-breasted Bunting & Emberiza aureola & w, 3 & Inskipp 1989 \\
\hline
\end{tabular}

$\mathrm{R}=$ resident, $\mathrm{b}=$ breeding confirmed, $\mathrm{w}=$ winter, $\mathrm{m}=$ migrant, $\mathrm{s}=$ summer, $1=$ common, $2=$ fairly common, $3=$ occasional, $4=$ uncommon, $5=$ rare 